Cuadernos del CILHA n 34-2021 | publicación continua

ISSN 1515-6125 | EISSN 1852-9615

http://revistas.uncu.edu.ar/ojs/index.php/cilha/

CC BY-NC 2.5 AR

Recibido: 14/05/2021 Aprobado: 15/06/2021

PP. 1-43

DOI: https://doi.org/10.48162/rev.34.005

\title{
De crímenes de familia a crímenes de
} Estado. La figura de la madre en la lucha contra la violencia de género en Crímenes de familia (2020) y Las tres muertes de Marisela Escobedo (2020)

From Family Crimes to State Crimes. The Figure of the Mother in the Fight Against Gender Violence in The Crimes that Bind (2020) and The three deaths of Marisela Escobedo (2020)

María Soledad Paz-Mackay iD https://orcid.org/0000-0002-7162-1547

Saint Francis Xavier University mpaz@stfx.ca Canadá

Argelia González Hurtado iD https://orcid.org/0000-0002-3288-8476

Saint Mary's College of Maryland agonzalezhurtado@smcm.edu Estados Unidos 
Resumen: El problema acuciante de violencia de género que vive Latinoamérica ha sido abordado recientemente por el cine de Argentina y México. En este artículo analizamos dos importantes representaciones, Las tres muertes de Maricela Escobedo de Carlos Pérez Osorio y Crímenes de familia de Sebastián Schindel. Basándose en historias reales, los directores recurren a diferentes estrategias para visibilizar y fomentar la discusión sobre la violencia contra mujeres y sus secuelas. En Crímenes de familia Schindel, se atrapa al espectador proponiendo un rompecabezas narrativo en el que poco a poco va introduciendo el tema por medio del suspenso. En Las tres muertes de Marisela Escobedo se expone a través del documental el calvario de una madre en búsqueda de justicia para su hija, víctima de feminicidio. A través del documental emocional y de denuncia, Pérez Osorio vigoriza el debate en torno a la justicia y la violencia de género. En este trabajo analizamos las estrategias narrativas elegidas por los directores para visibilizar y agudizar el debate alrededor de temas complejos como la violación, homicidio agravado por el vínculo y el feminicidio. En segundo lugar, nos centraremos en la perspectiva de la madre que reformula en su devenir temas cruciales como la toma de conciencia, la falta de justicia, la sororidad y el activismo. Por último, analizamos la elección de ambas películas de ser co-producidas y distribuidas por Netflix. Argüimos que estos estos tres elementos se combinan para conformar lo que Rita Segato llama una "contra-pedagogía de la crueldad".

Palabras clave: Argentina, Feminicidio, México, Netflix, Violencia de género.

Abstract: The pressing problem of gender violence in Latin America has recently been addressed in the cinema of Argentina and Mexico. In this article, we analyze two representations of this important topic in the films The Three Deaths of Maricela Escobedo by Carlos Pérez Osorio, and The Crimes that Bind by Sebastián Schindel. Based on real life stories, the directors use different strategies to visibilize and encourage discussion about the violence against women and its consequences. In The Crimes that Bind, Schindel sets the story in the drama genre and engages the spectator by proposing a narrative puzzle in which he introduces the topic, little by little, through elements of suspense. In The Three Deaths of Marisela Escobedo Pérez Osorio exposes through the use of documentary, the ordeal of a mother in search of justice for her daughter, victim of femicide. Through the emotional and social justice documentary, Pérez Osorio invigorates the debate around justice and gender violence. Our article analyzes the narrative strategies chosen by the directors to make visible and sharpen the debate around complex issues such as sexual assault, homicide aggravated by familial relationship and femicide. Second, we will focus on the construction of the perspective of the mother who conveys crucial issues such as awareness of gender violence, lack of

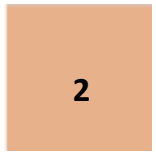

Cuadernos del CILHA n $34-2021$

ISSN 1515-6125 | EISSN 1852-9615

CC BY-NC 2.5 AR

http://revistas.uncu.edu.ar/ojs/index.php/cilha/ 
justice, sorority and activism. Finally, we analyze the choice of both films to be coproduced and distributed by Netflix. We argue that the combinations of these three strategies contribute to form a "contra pedagogy of cruelty", a term coined by Rita Segato.

Keywords: Argentina, Femicide, Mexico, Netflix, Gender violence.

En Argentina y México, el problema acuciante de violencia de género ha sido abordado recientemente en la industria cinematográfica en colaboración con Netflix, una de las nuevas plataformas de servicio de video por demanda. En este artículo analizamos dos importantes representaciones en el 2020, el documental Las tres muertes de Marisela Escobedo dirigido por Carlos Pérez Osorio y la película Crímenes de familia dirigida por Sebastián Schindel. Basándose en historias reales, los directores recurren a diferentes estrategias para visibilizar y fomentar la discusión sobre la violencia contra mujeres y sus secuelas. Estas películas reflejan tan sólo una muestra del amplio repertorio de formas de violencia predominantes en Latinoamérica. En particular, las películas abordan la violencia doméstica y sus consecuencias y el feminicidio. Aunque las películas analizadas muestran un tipo específico de violencia de género, no excluye la existencia de otros tipos de violencia contra mujeres en cada uno de estos países. La sagacidad de los directores de acercarse a temas tan complejos intensifica la urgencia de dimensionar la gravedad de la situación abriendo la discusión. Asma Sayed (2016) señala que las cinematografías del mundo, históricamente, han representado la figura de la madre en una forma estereotipada, relegándola a un papel periférico en el que la narrativa se enfoca en el esposo, el hijo o la hija (p.5). En el cine latinoamericano, sobre todo de corte comercial, la representación de la madre ha sido una de las más formulaicas y estereotipadas a través del uso de géneros cinematográficos como el melodrama. Un claro ejemplo se observa durante la época de oro del cine mexicano (1930 a 1950) en donde se beatifica la figura de la madre mediante filmes de corte melodramático, convirtiéndose de esta manera en uno de los ejes retóricos del cine mexicano (Aviña p. 136; Tuñón p. 185). Al igual que en el cine mexicano de la época de oro, en la cinematografía argentina nacional también se distingue una obsesión por santificar la figura de la madre. Tal como lo señala Fernando Pagnoni Berns, "en el cine clásico argentino (1936 a 1950) el papel de la madre es claro y sin ambigüedades: sacrificarse por el bien de sus hijos -incluso dando su propia vida si fuera necesario- 
De crímenes de familia a crímenes de Estado. La figura de la madre en la lucha contra la violencia de género en Crímenes de familia (2020) y Las tres muertes de Marisela Escobedo (2020)

para que pudieran ser promovidos social, económica y culturalmente" (p. 281) ${ }^{1}$. Agrega que en las producciones del siglo XX dominan los discursos idealizados de la 'madre buena', al que se opone la idea de 'mala madre' creando un binarismo sobre la maternidad. En Latinoamérica, este rol de la mala madre se observa en el arquetipo de la Llorona que acentúa el lado monstruoso de la maternidad. Así, el personaje de la madre abnegada y de la mala madre se instituyen como legados en estas cinematografías, reafirmando las estructuras patriarcales dominantes en ambas sociedades.

En ese sentido, de acuerdo con Sayed, las experiencias de la maternidad, tanto fuera de la pantalla como dentro de esta, son complejas y en constante cambio (p. 2). Estas experiencias están moldeadas por los momentos históricos, culturales y económicos en que las mujeres viven su maternidad. Todo esto se ve reflejado en la existencia de películas de ficción y no-ficción que, resistiendo al estereotipo tradicional de la madre, no solo traen su figura al centro de la narrativa, sino que abordan temas de candente actualidad que las involucran y afectan directamente. Por ejemplo, Pagnoni Berns menciona que el modelo de la madre tradicional cambió en Argentina con el regreso de la democracia a ese país (p.281). Mientras que, en México, Isabel Arredondo (2014) señala que, gracias a la incursión de directoras cinematográficas, las imágenes sobre la maternidad se modifican al contextualizar social, económica y judicialmente la situación del personaje (p.187). La evolución de la representación cinematográfica de lo maternal evidencia no solo la apertura y pluralidad de sentidos otorgados a la misma, sino que también expone los problemas que las afectan. Actualmente, las sociedades latinoamericanas atraviesan un momento histórico sin precedentes, en relación con la violencia género a la que se enfrentan las mujeres. Dicha violencia no sólo ha permeado todas las capas de la sociedad, sino que ha invadido espacios de la experiencia del ser mujer, como la maternidad.

Bajo este contexto, exploramos el papel de la madre en la película de ficción argentina Crímenes de familia (2020) de Sebastián Schindel y el documental mexicano Las tres muertes de Marisela Escobedo (2020) de Carlos Pérez Osorio. En estas películas, la

\footnotetext{
${ }^{1}$ Nuestra traducción.
} 
madre no sólo es el centro de la narrativa, sino que a través de ella se expone la brutal realidad de violencia en contra de las mujeres. Nuestro análisis se enfoca en las estrategias fílmicas utilizadas en ambos formatos (ficción y documental) para representar la figura de la madre. En primer lugar, tomando en cuenta que ambas películas indagan la violencia en contra de las mujeres, analizamos los elementos formales y las estrategias cinematográficas elegidas por cada director para representar dicha violencia. En segundo lugar, estudiamos el personaje de la madre y su punto de vista, utilizado como vehículo narrativo para revelar la violencia de género. A su vez, examinamos cómo esta se entreteje con estructuras de poder, clase social, patriarcado tanto en la esfera privada y pública en Argentina y México. Por último, sostenemos que la elección de los directores de utilizar estrategias fílmicas específicas tiene como objetivo informar, educar y denunciar de una manera aguda cuestiones de violencia contra la mujer para espectadores nacionales y transnacionales. Argüimos que estas decisiones fílmicas sumadas a la elección de la plataforma de difusión, Netflix, funcionan como estrategias de contra-pedagogía de la crueldad, concepto acuñado por Rita Segato (2018 p. 209).

Usando el género del drama como lienzo, Crímenes de familia atrapa la atención del espectador mediante el efectivo uso de elementos de suspenso y lo invita a reflexionar sobre temas urgentes y actuales en la sociedad argentina: la violencia de género y la precariedad de las condiciones de trabajo de las empleadas domésticas. La película, producción original de Netflix, narra paralelamente dos historias centradas en torno a una familia de clase media-alta en Buenos Aires, conectadas mediante el personaje central de la madre, Alicia (Cecilia Roth). Por un lado, trata de los problemas judiciales del hijo único acusado de violación e intento de homicidio de su exesposa; y por el otro, el juicio que afronta Gladys (Yanina Ávila) la empleada doméstica de esta familia, quien vive con ellos. Los espectadores descubren poco a poco, a medida que avanza el juicio, el crimen del que se le acusa a Gladys. Al mismo tiempo, mediante la introducción de elementos de suspenso se devela el horror detrás de este crimen. Como se ha señalado, la historia se cuenta desde el punto de vista de Alicia, así los espectadores son testigos de su transformación, ya que pasa de defender a toda costa la inocencia de su hijo Daniel (Benjamín Amadeo), a convertirse en una aliada de su exnuera al descubrir la 
De crímenes de familia a crímenes de Estado. La figura de la madre en la lucha contra la violencia de género en Crímenes de familia (2020) y Las tres muertes de Marisela Escobedo (2020)

verdadera historia de abuso sufrida a manos de su hijo. De esta manera, en Crímenes de familia nos enfocamos en la función que cumple el drama y el suspenso como dispositivos para evidenciar la violencia en el contexto familiar, y para mostrar la transformación de la protagonista en su toma de conciencia sobre las consecuencias de la violencia de género.

Por su parte, siguiendo características del documental social latinoamericano Las tres muertes de Marisela Escobedo trae a la lista de documentales producidos por Netflix el conocido caso de la activista Marisela Escobedo a diez años de su asesinato². El documental narra el calvario de una madre, Marisela Escobedo, a raíz de la desaparición y asesinato de su hija de 17 años, Rubí Marisol Frayre Escobedo. La serie de adversidades que Escobedo enfrenta para capturar y enjuiciar al asesino de su hija, la transforma de madre y enfermera a detective y activista. El documental se centra en tres momentos cruciales (tres muertes) de la vida de Marisela. El primero, es el asesinato de su hija a manos de su novio, Sergio Rafael Barraza Bocanegra en Ciudad Juárez, Chihuahua. El segundo momento crítico, es el juicio de Barraza que, tras su arresto, confiesa haberla matado ante la amenaza de Rubí de abandonarlo, y señala el lugar donde quemó y desechó su cuerpo. Sin embargo, Barraza es absuelto y puesto en libertad por supuestas fallas en el proceso. El tercero, marca el inicio de la intensa cruzada de Marisela como activista por diversas partes de México para lograr nuevamente la captura del Barraza y tener un proceso judicial justo. Finalmente, Marisela es asesinada mientras exigía justicia frente al palacio de gobierno de Chihuahua. Este documental es construido por medio de diversas entrevistas a los hijos y familiares de Marisela, representantes legales, autoridades oficiales y otros activistas. El documental incorpora recursos como recreaciones, imágenes de diversos medios de comunicación y fotos del archivo personal de Marisela y su familia. Sin lugar a duda, es la recopilación de los testimonios de Marisela hecha por el director el principal recurso dramático de este trabajo. Con esto, Pérez Osorio recupera la voz e historia de la activista.

2 Las tres muertes de Marisela Escobedo es uno de los 39 documentales bajo el sello de producciones originales de Netflix, estrenados en 2020.

Cuadernos del CILHA n $34-2021$

ISSN 1515-6125 | EISSN 1852-9615

6

CC BY-NC 2.5 AR

http://revistas.uncu.edu.ar/ojs/index.php/cilha/ 


\section{Violencia contra las mujeres}

En este artículo entendemos la violencia contra las mujeres, tal como la define el Articulo 1 de la Convención Belem do Pará, como "cualquier acción o conducta, basada en su género, que cause muerte, daño o sufrimiento físico, sexual o psicológico a la mujer, tanto en el ámbito público como en el privado" (1994). La Organización Mundial de la Salud (OMS) señala que la violencia contra las mujeres figura tanto como una de las mayores violaciones a los derechos humanos como un problema de salud a nivel mundial. Las estadísticas de la OMS (2021) indican que al menos una de tres mujeres entre 15 años o más ha sufrido algún tipo de violencia sexual, perpetrados ya sea por parte de su pareja íntima o por un extraño (p. XVI). Estas cifras son alarmantes ya que no incluyen en las estadísticas los otros tipos de violencia como la psicológica, económica, o feminicidios. Así la OMS indica que de manera inequívoca la violencia contra de las mujeres alcanza proporciones pandémicas que ocurre en todos los sectores de la sociedad y que requiere acciones urgentes para erradicarla ( $p$. XIX). De acuerdo con Tamar Wilson, en América Latina las mujeres han enfrentado diversos tipos de violencia, como torturas y violaciones durante la guerra civil o bajo militancia, abusos domésticos y feminicidios (2014, p. 4). Esta violencia está ligada tanto a la cultura machista que impera en las sociedades latinoamericanas como a las condiciones estructurales y sistémicas o violencia estructural que han mantenido subordinadas a las mujeres. Menciona que la violencia estructural se puede dividir al menos en dos tipos, la ideológica y cultural que está relacionada con el (neo)patriarcado, el machismo y las religiones; y la relacionada con cuestiones sociales y económicas que perpetúan entre otras cosas desigualdades de clase, étnicas y raciales. La violencia estructural se ejerce cuando las mujeres cuestionan y se revelan ante la subordinación que estas estructuras ejercen sobre ellas (p. 5). En este sentido, la violencia contra las mujeres no se debe tomar como acciones aisladas, sino que se deben analizar los contextos donde surgen, así como las estructuras materiales y abstractas que la producen. Crímenes de familia y Las tres muertes de Marisela Escobedo brindan ejemplos claros de esta violencia 
De crímenes de familia a crímenes de Estado. La figura de la madre en la lucha contra la violencia de género en Crímenes de familia (2020) y Las tres muertes de Marisela Escobedo (2020)

estructural y dan guiños del contexto que la genera al presentar casos específicos de violencia como la doméstica, de clase social y el feminicidio.

En México es muy conocida la situación de violencia extrema a la que se enfrentan las mujeres y niñas por los casos de feminicidio que surgieron a partir de 1993 en Ciudad Juárez, Chihuahua. Si bien los feminicidios se vieron primero como un fenómeno focalizado en esa ciudad fronteriza, el registro sistemático sobre estos crímenes en México ha arrojado que son un problema recurrente en todas las entidades de la República mexicana (Incháustegui Romero, 2014 p. 373). Esta violencia extrema es solo una muestra de la violencia generalizada en México hacia las mujeres y las niñas. De acuerdo con un reporte de la Organización de Naciones Unidas (2018), "al menos 6 de cada 10 mujeres mexicanas ha sufrido un incidente de violencia; $41.3 \%$ de las mujeres ha sido víctima de violencia sexual y, en su forma más extrema, 9 mujeres son asesinadas al día. Otras estadísticas que muestran contundentemente la violencia contra las mujeres en México es el contraste entre los casos de homicidios de hombres y mujeres, ya que mientras "Ios homicidios de varones se concentran entre 18 y 30 años comenzado a declinar a los 40", los feminicidios se producen en todas las edades (Incháustegui Romero, 2014 p. 391). En esta violencia extendida convergen varios factores estructurales como la misoginia, la construcción social de masculinidad y feminidad, el crecimiento del crimen organizado, y las transformaciones sociopolíticas del país. Teresa Incháustegui Romero (2014) arguye que el carácter casi epidémico de la violencia en México pudo haberse evitado si las autoridades hubiesen cumplido con su deber de investigar los casos y castigar a los responsables. Señala que, la mayoría de los casos de violencia contra las mujeres como feminicidio, violación o lesiones, concluyen en la impunidad de los perpetradores y en la ausencia de garantías y derechos humanos de las víctimas ocasionadas por diversas causas relacionadas con las autoridades (p. 395). De esta manera, debe sumarse a la violencia ejercida por individuos, la violencia institucional como es mostrado en Las tres muertes de Marisela Escobedo.

En Argentina, en sentido similar, la omnipresencia de la violencia de género ha resaltado los serios problemas estructurales existentes en toda la sociedad y también las numerosas falencias por parte de las instituciones gubernamentales. En el nuevo 
siglo, la escalada de crímenes hacia mujeres y niñas ha generado horrendas consecuencias en todo el país. Esto se refleja en las estadísticas que revelan un estremecedor aumento de feminicidios, uno cada 35 horas en el año 2020. La Asociación Civil La Casa del Encuentro produjo el primer informe oficial en el año 2008, ante la ausencia de estadísticas oficiales. En el 2009, dicha asociación civil conformó el Observatorio de Femicidios en Argentina "Adriana Marisel Zambrano" bajo la dirección de Ada Beatriz Rico ${ }^{3}$. Las cifras recogidas en el último informe, que abarca el periodo desde el 20 de marzo del 2020 al 20 de marzo del 2021, presentan la estremecedora evidencia: 287 mujeres se convirtieron en víctimas de femicidio en el país y sólo 35 de ellas habían denunciado violencia de género. Asimismo, las estadísticas revelan el alto número de niños que quedan sin madres como consecuencia de estos crímenes: 321 hijos, de los cuales el $61 \%$ son menores de edad. Por su parte, la Oficina de la mujer, creada también en el 2009, dependiente de la Corte Suprema de Justicia de la nación, ha recogido números similares a los presentados por la Casa del Encuentro. Según el informe, presentado por la doctora Elena Highton de Nolasco, a cargo de la Oficina de la Mujer, durante el 2020 se registraron 287 víctimas letales: 251 de femicidio directo y 36 de femicidio vinculado 4 . Dicho registro identificó también que "en el $84 \%$ de los casos, la víctima conocía al sujeto, que en el $59 \%$ era pareja o expareja, y en el $48 \%$ convivían"; también que el $63 \%$ de los casos ocurrieron en la vivienda de la víctima. Estas estadísticas evidencian la magnitud y gravedad de la violencia de género que se ha convertido en la triste realidad que se vive en Argentina actualmente.

En relación con la violencia estructural, María Lugones (2007) articula sus ideas sobre el heterosexismo explicando cómo el concepto de género se funde con el concepto de

\footnotetext{
${ }^{3}$ El observatorio lleva el nombre de una joven de 28 años, de Palpalá, Jujuy, que fue asesinada a golpes por su ex pareja. El observatorio ha producido informes en los últimos 10 años con los siguientes objetivos: "Realizar un aporte desde la sociedad civil para consolidar un proceso de desnaturalización de la violencia sexista, comenzando por el lenguaje, instalando la definición de Femicidio, tanto en los medios de comunicación como en la sociedad. Incidir en políticas públicas integrales de protección hacia las mujeres, los niños".

${ }^{4}$ De acuerdo con lo definido por el informe de la Oficina de Mujeres, por femicidio vinculado se entiende, a los homicidios directamente relacionados a la violencia de género, incluyendo tres categorías 'vinculados", "vinculados por armas de fuego' y "otras muertes vinculadas por violencia de género".
} 
De crímenes de familia a crímenes de Estado. La figura de la madre en la lucha contra la violencia de género en Crímenes de familia (2020) y Las tres muertes de Marisela Escobedo (2020)

raza para el funcionamiento de las relaciones impuestas por el poder colonial (p. 186). En opinión de Lugones, el colonialismo impuso un nuevo sistema de género que determinó un estrato de reglas diferentes entre el colonizador burgués y los hombres y mujeres colonizados, lo que introdujo el concepto de género mismo como un modo de organización de relaciones. Para Lugones, es indispensable historizar el sistema de género para remover del centro de la reflexión al sistema jerárquico y binario del patriarcado. Explica Lugones (2008) que “Aníbal Quijano concibe la intersección de raza y género en términos estructurales amplios. Para entender su concepción de la intersección de raza y género hay que entender su análisis del patrón de poder capitalista Eurocentrado y global" (p. 78). Lugones considera esta visión de Quijano como limitada desde que presupone una compresión patriarcal y heterosexual de las disputas por el control del sexo y sus recursos y productos (2008, p.78). En consecuencia, decide desarrollar sus ideas sobre la colonialidad del poder desde un lugar en el cual las relaciones sociales no están organizadas desde el sistema de género patriarcal y heterosexual. De allí deriva su interés por historizar el sistema moderno colonial de género que entiende como central para una comprensión de la organización diferencial del género en términos raciales. El claro e importante aporte de Lugones se centra alrededor de su idea de que los colonizadores blancos impusieron un sistema poderoso en el mundo colonizado, logrando establecer a los hombres colonizados dentro de los roles patriarcales impuestos, el que se continúa reproduciendo hasta nuestros días. En ambas películas analizadas en este ensayo se presentan mujeres violentadas en sus propios hogares dentro de su mundo privado. Asimismo, tanto Verónica como Gladys, y Rubí pertenecen a la clase trabajadora y son mestizas y no gozan de los mismos privilegios que las mujeres de clase alta, como Alicia. Todos estos factores confluyen en la determinación de su lugar de víctimas de la violencia de género, en manos de miembros de su círculo íntimo de allegados.

De acuerdo con Segato (2018), en Latinoamérica existe una naturalización de la violencia contra las mujeres evidenciando un comportamiento generalizado sobre la violencia, lo que conduce a los bajos niveles de empatía ante la problemática (p. 202). Además, agrega que "la crueldad habitual es directamente proporcional a formas de gozo narcísico y consumista, y al aislamiento de los ciudadanos mediante su desensitización al sufrimiento de los otros" (2021). Para la autora, una cuestión

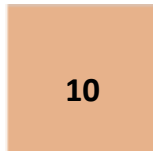

Cuadernos del CILHA n $34-2021$

ISSN 1515-6125 | EISSN 1852-9615

CC BY-NC 2.5 AR

http://revistas.uncu.edu.ar/ojs/index.php/cilha/ 
importante de esta naturalización es que muchas mujeres no se identifican como víctimas de violencia de género ya que lo internalizan como un fenómeno "normativo", es decir, esas acciones se observan como parte del conjunto de las reglas que se ven como la normalidad, normas que han sido establecidas desde el patriarcado (2003 p. 3). De esta manera, los actos de violencia sistémica que existen en Latinoamérica, incluyendo los de género, representan lo que la autora ha acuñado como el concepto de "pedagogías de la crueldad". Segato (2018) define estas pedagogías como "todos los actos y prácticas que enseñan, habitúan y programan a los sujetos a transmutar lo vivo y su vitalidad en cosas" (p. 209). Para la académica ejemplos y alegorías de la pedagogía de la crueldad son la trata y la explotación sexual que cosifican a las mujeres en productos de consumo. Además, menciona que, en el contexto de la pedagogía de la crueldad, los medios masivos de información juegan un rol importante en la cosificación de la violencia contra las mujeres "con su lección de rapiña, escarnio y ataque a la dignidad ejercitadas sobre el cuerpo de las mujeres" (2003, p. 4).

Para erradicar la violencia y la naturalización de ésta, Segato propone una contrapedagogía de la crueldad con el objetivo de crear y nutrir relaciones que enseñen a valorar a las personas como personas, desafiando de esta manera, la normalización de la violencia (2021). Para lograr una contra-pedagogía de la crueldad, Segato sugiere fortalecer "el amor, las relaciones de amistad, el cuidado mutuo y la responsabilidad por nuestros semejantes" (2021). Así, esta estrategia pedagógica desmantela las estructuras impuestas por el patriarcado al mostrar valores que sensibilizan el sufrimiento de otros. Además de una contra-pedagogía y de un cambio estructural, en forma de leyes, por ejemplo, debe existir herramientas que busquen una concientización sobre la violencia (Segato, 2003, p. 4). Es aquí donde los medios de comunicación son aliados indispensables por su poder de difusión masiva. En este artículo afirmamos que Crímenes de familia y Las tres muertes de Marisela Escobedo ofrecen una lectura en el sentido mencionado por Segato. Ambas funcionan como estrategias de contra-pedagogía de la crueldad, tanto por su carácter didáctico e informativo sobre diferentes tipos de violencia como por su intención de formar lazos comunitarios. En cada obra se resalta la importancia de la formación de vínculos 
De crímenes de familia a crímenes de Estado. La figura de la madre en la lucha contra la violencia de género en Crímenes de familia (2020) y Las tres muertes de Marisela Escobedo (2020)

comunitarios y en específico, las dos películas eligen destacar el sentido de la sororidad necesario en la actualidad de ambos países.

Tal como hemos señalado, ambas películas se destacan por el contenido y el mensaje, y también por la estrategia de producción y distribución seleccionada. Es notable que ambas películas no sigan los canales tradicionales, tanto de producción como distribución, establecidos en Latinoamérica. Ambas obras fueron producidas y distribuidas por Netflix que es una de las empresas de entretenimiento audiovisual más importantes a nivel mundial; la cual sigue el modelo de video bajo demanda (VBD) que permite al usuario acceder a un contenido de su preferencia por medio un servicio de libre transmisión, vía internet o de algún dispositivo (OTT). En el 2011 Netflix abrió sus servicios en 43 países de Latinoamérica y el Caribe como parte de la estrategia de expansión a otros mercados fuera de Estados Unidos y Canadá. En Latinoamérica, el mercado de televisión por internet se ha extendido, presentando competidores nacionales e internacionales a Netflix. No obstante, este se ha mantenido como líder de estos nuevos servicios de acceso de contenidos audiovisuales. En México, Netflix tiene alrededor de 8.3 millones del total de suscriptores, mientras que en Argentina existen cerca de 4.5 millones de usuarios (Cornelio-Marí 2020 p. 5, Mármol 2020). Estas cifras posicionan a México y Argentina entre los primeros diez países con más suscriptores de Netflix. Elia Cornelio-Marí (2020) explica que parte del éxito de Netflix en la región se debe a la estrategia usada por la compañía en donde se tomó en cuenta las tendencias locales de cada mercado. De acuerdo con Cornelio-Marí, esta estrategia comprendió primero, la creación de una versión específica del sitio para cada mercado; segundo, procedieron con el doblaje y subtitulado de los contenidos hollywoodenses y europeos al español latino; y finalmente, se crearon contenidos con base en las preferencias de la audiencia latinoamericana donde predominan los géneros de la comedia y el melodrama (p. 8). Es en la última fase de la estrategia de expansión de Netflix en la cual se ubican Crímenes de familia y Las tres muertes de Marisela Escobedo.

Al colaborar con Netflix, los productores de ambas películas logran cierta independencia de los monopolios mediáticos en Argentina y México, que por años han controlado y condicionado contenidos y vías de distribución de las compañías productoras. Como señalan Mariela Baladrón y Ezequiel Rivero (2019), históricamente 
los medios comerciales se han caracterizado por ser empresas muy centralizadas y con una línea editorial progobierno (p. 113). Señalan que los principales grupos de medios de la región como Televisa, Globo, Clarín "se convirtieron en grandes empresas que acaparan casi todos los mercados de las info-comunicaciones desde las dos últimas décadas del siglo XX". Así la apuesta de trabajar con Netflix además de abrir un espacio para aquellos directores que no comulgan con las filosofías de los monopolios, representa otra forma de obtener recursos para producir y crear nuevos contenidos. También, la exposición a nivel mundial de la plataforma proporciona de una manera más rápida e inmediata la llegada a otros mercados. La elección de la plataforma se justifica aún más porque, en Argentina, la violencia de género ha sido tratada en los medios de comunicación de la última década de una manera que diluye la verdadera dimensión del problema. Según lo entiende Claudia N. Laudano (2010), el recurso simbólico del "crimen pasional" se ha convertido en una "mercancía bien cotizada en la industria cultural del presente" (p. 100). En su opinión, de este uso mediático se derivan consecuencias importantes para diferentes sectores sociales. Para Laudano, la primera consiste en la anulación de las críticas a la ineficiencia del Estado en su responsabilidad de proteger la vida de las mujeres, desde que se categoriza al como "acontecimientos

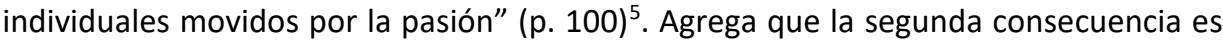
la abierta tolerancia de estas prácticas de ejercicio violento contra mujeres, lo que refuerza el ejercicio del poder patriarcal. Para esta académica, la tercera consecuencia es movilizar limitadamente a la ciudadanía en el consumo informativo, sin acentuar la exigencia de una solución permanente de una vida libre de violencia. Como un rechazo a este tratamiento de la violencia de género en los medios de Argentina surge el movimiento \#Niunamenos en Buenos aires en el $2015^{6}$. De manera similar, en México se ha observado que los medios de comunicación, por lo general, muestran las noticias sobre feminicidio como casos individuales y no como un problema social de interés

\footnotetext{
${ }^{5}$ En relación con el concepto de crímenes pasionales, Laudano sostiene que los mismos "operarían como el recurso melodramático por excelencia ante rasgos perturbadores del "desborde emocional", que interpelan más lo insondable de una época que su dimensión inteligible" (98).

${ }^{6}$ Tal como lo explica Cecilia Palmeiro (2019) "un grupo de periodistas, escritoras, artistas y comunicadoras profesionales comenzó a imaginar una contra-narrativa frente a la ofensiva misógina que asolaba los medios de comunicación hegemónicos" (p. 179).
}

Cuadernos del CILHA n 34 - 2021 
De crímenes de familia a crímenes de Estado. La figura de la madre en la lucha contra la violencia de género en Crímenes de familia (2020) y Las tres muertes de Marisela Escobedo (2020)

público. Los feminicidios son atribuidos a una disfunción individual debido a factores como el alcoholismo, drogadicción, o agresividad por parte del victimario. Mientras que la información que se reporta sobre las víctimas se centra en resaltar factores como la pobreza, pasividad, en la que se construye una imagen entre mujeres buenas y malas (Tiscareño-García y Miranda Villanueva, 2020). De acuerdo con Julia Monárrez Fragoso (1993), la prensa refuerza las nociones de poder y control del patriarcado al estigmatizar a las víctimas de feminicidio influyendo a "quién sí y por quién no se debe tener compasión" (p. 374). Señala que, por ejemplo, las niñas que son asesinadas reciben atención y consuelo de los medios; mientras que las víctimas que trabajan en ocupaciones estigmatizadas son presentadas como merecedoras de su asesinato ( $p$. 374). Es la sociedad civil por medio de los movimientos feministas y de mujeres que en su constante activismo proporcionan una dimensión más social y de interés público sobre el problema de la violencia contra las mujeres.

\section{El punto de vista de las madres: de la toma de conciencia al activismo.}

Cómo se ha expuesto, uno de los mayores desafíos que enfrentan las mujeres en Latinoamérica y alrededor del mundo es la omnipresencia de la violencia de género en todas las estructuras sociales. Tal como lo expresa Sayed, es necesario prestar atención a la representación fílmica de los personajes de las madres por lo que éstas reflejan de la cultura, al mismo tiempo que la retroalimentan afectando actitudes e ideas acerca de roles, relaciones y los potenciales de mujer y madre $(p .1)^{7}$. Las películas en estudio ofrecen una representación de la violencia de género que afecta a mujeres en las sociedades de México y Argentina del Siglo XXI. En ambas, las historias giran en torno a las complejas experiencias vividas por los personajes femeninos derivadas de dicha violencia. En particular, nos centramos en el estudio de los personajes femeninos que experimentan cambios importantes en su rol de madres a lo largo de los filmes como consecuencia de la violencia de género. A su vez, sostenemos que el espectador, al ser testigo de ese cambio, se concientiza de la gravedad del fenómeno de la violencia y aprende junto a las protagonistas sobre la sororidad y el activismo. En ese sentido, se observa una evolución de la figura de las madres ya que tanto Crímenes de familia como

\footnotetext{
${ }^{7}$ Los Estudios sobre maternidad o Motherwood Studies han ganado atención en las últimas tres décadas con los aportes de académicos como Adrienne Rich, Patricia Hill Collins y Andrea O'Reilly entre otros.
}

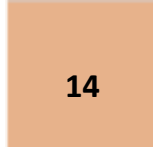

Cuadernos del CILHA n $34-2021$

ISSN 1515-6125 | EISSN 1852-9615

CC BY-NC 2.5 AR

http://revistas.uncu.edu.ar/ojs/index.php/cilha/ 
Las tres muertes de Marisela Escobedo se alejan del estereotipo de madres sumisas o ideales. Por el contrario, las mismas se centran en representaciones de madres que se enfrentan abiertamente a las adversidades que sufren sus familias; y de esta manera evolucionan en su rol y compromiso materno reformulando con ello la maternidad, al presentar variantes que agregan a la multiplicidad de este rol. Alicia y Marisela dejan de ser madres tradicionales para convertirse en aliadas en Crímenes de familia y activistas en Las tres muertes de Marisela Escobedo, y con esto, desafían y cuestionan las estructuras patriarcales que les asignan un rol pasivo y apolítico a las mujeres.

Alicia en Crímenes de familia es una madre, ama de casa, de una familia de clase mediaalta que pasa sus días ocupada con visitas con amigas, clases de yoga y ayudando a la empleada doméstica, Gladys, en la educación de su niño. Al comienzo, Alicia es una madre tradicional, aunque a medida que va conociendo la verdad de los eventos que involucran a su hijo único, lo deja de defender ciegamente para solidarizarse con su exnuera y nieto, y también con Gladys y su hijo. Daniel es acusado de violación e intento de homicidio contra su exesposa Marcela ${ }^{8}$. Alicia primero no duda en pagar $\$ 400.000$ dólares para hacer desaparecer el expediente judicial de la causa contra su hijo, cuando ya no había más recursos legales para defenderlo. Más adelante en la película, y ya convencida de los crímenes que ha cometido su hijo y las nefastas consecuencias de estos, Alicia se acerca a la casa de su exnuera para entregarle el expediente, lo que permitirá el encarcelamiento de Daniel. De esta manera, Alicia se convierte en una aliada de su exnuera, y también continúa ayudando a Nancy al hacerse cargo de la crianza del hijo de esta ${ }^{9}$. Por su parte, en Las tres muertes de Marisela Escobedo, Marisela es una madre dedicada a su familia, a la crianza de sus hijos y su trabajo como enfermera, pero una vez que su hija Rubí, de tan solo 17 años, desaparece, comienza su transformación. Primero, ella se convierte en investigadora para llegar a la verdad

\footnotetext{
${ }^{8}$ Daniel ya tenía una sentencia con cumplimiento condicional, pero con la segunda causa, ya no es posible mantenerlo fuera de la cárcel.

${ }^{9}$ Para el espectador de Argentina, el nombre de la protagonista, Alicia, evoca, La historia oficial (1986). En esta película, la protagonista, Alicia, se transforma y deja de ser una madre pasiva ya que abre los ojos a la realidad del robo de niños, hijos de desaparecidos, durante la dictadura militar, lo que la afecta directamente y confronta a su marido por esto.
} 
De crímenes de familia a crímenes de Estado. La figura de la madre en la lucha contra la violencia de género en Crímenes de familia (2020) y Las tres muertes de Marisela Escobedo (2020)

de lo que le había pasado a su hija. Segundo, y una vez descubierto el feminicidio, Marisela comienza su activismo durante el juicio, con las caminatas para pedir la condena con pena máxima, y lo continúa después de que el tribunal lo absuelve ${ }^{10}$. El activismo de Marisela se expande luego de la absolución del yerno y alcanza un nivel nacional al recorrer todo el país en busca de justicia. Marisela llega a interpelar no sólo a las autoridades locales, sino que sus demandas son dirigidas tanto a gobernadores estatales como al presidente de la república. Aunque las autoridades oficiales hacen caso omiso a las peticiones de la activista, la opinión pública acoge su lucha al difundir y conectarla con organizaciones civiles. Su cambio, de madre a activista, la muestra como una mujer determinada por descubrir la verdad de los hechos y obtener justicia por el crimen cometido por su exyerno.

La decisión de los directores de destacar la perspectiva que brindan Alicia y Marisela en las películas en estudio es medular por el mensaje que transmiten sobre los nuevos roles maternos. Y a su vez ponen en el centro de discusión las deficiencias de nuestra sociedad en cuanto a la omnipresencia de la violencia hacia las mujeres. Estas madres, si bien transitan el camino de la violencia de género desde lugares diferentes, su esfuerzo y aprendizaje revelan un contexto de crueldad y poca solidaridad. En los estrados judiciales, Marisela defiende el lugar de su hija Rubí, víctima de un feminicidio; mientras que Alicia al principio protege a su hijo Daniel, el agresor y victimario, para luego dejar de hacerlo cuando conoce la verdad de los hechos, y elige en contra de su lazo familiar directo. Si bien las circunstancias alrededor de la violencia de género presentadas en las dos películas son muy diferentes, en ambas las madres descubren que es necesario priorizar la solidaridad entre mujeres para salir adelante de esta violencia de género. Marisela paga el precio más alto, su vida, ya que la asesinan en

\footnotetext{
${ }^{10}$ En México, el caso de Rubí Frayre Escobedo representó uno de los primeros casos de feminicidio que se realizó bajo el Nuevo Sistema de Justicia Oral o Acusatorio Advesarial que sustituyó al Inquisitivo que tenía un formato escrito. Otro cambio importante que se hizo en el sistema judicial mexicano fue el de legislar contra el uso de la violencia para obtener una declaración del acusado que era común en un Sistema Inquisitivo. El artículo 20 de la Constitución Federal Mexicana reconoce la existencia de una garantía a la libertad de declarar y el derecho del imputado a no incriminarse y contar con la asistencia de una defensa adecuada. Por lo que la declaración de un imputado debe ser un medio de defensa y no uno de prueba, es decir, la carga de la prueba le corresponde al ministerio público. Así, un imputado no puede ser obligado a declarar y siempre que declare debe estar acompañado de un abogado, sin esto su declaración se considera ilegal, que es lo que sucedió en el caso de Sergio Barraza.
}

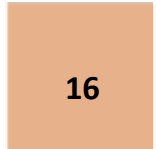

Cuadernos del CILHA n $34-2021$

ISSN 1515-6125 | EISSN 1852-9615

CC BY-NC 2.5 AR

http://revistas.uncu.edu.ar/ojs/index.php/cilha/ 
medio de una protesta al marchar pidiendo justicia para su hija. Por su parte, Alicia opta por dejar su vida de apariencia y privilegio, y elige crear nuevos vínculos familiares que considera fundamentales, con su exnuera y nieto, y con Gladys y su hijo. Esa decisión implícitamente conlleva reconocer su situación de mujer privilegiada, y así esto le permite abrirse a una nueva realidad al admitir la violencia de género a su alrededor.

En relación con la representación de la maternidad en el cine de Argentina, Pagnoni Berns explica que, a partir de 1983, se produce un cambio en los discursos hegemónicos de la "madre ideal" para dar paso a nuevas configuraciones de lo materno como "singularidades" (p. 281). En su opinión, los personajes madres protagonistas de películas de finales del siglo $X X$, ya no reproducen discursos sociales sin cuestionamientos, sino por el contrario promueven la maternidad como un continuo proceso (p. 281). En Crímenes de familia, la perspectiva de Alicia es un ejemplo de ese continuo proceso de cambio y evolución del rol de madre. Alicia proporciona una particular mirada de clase, y los privilegios que la misma conlleva; por ejemplo, su lugar privilegiado le permite apurar el paso a juicio oral de su hijo, porque su abogado conoce al juez. También su poder económico le proporciona la oportunidad de pagar a un abogado defensor para que le 'desaparezca' el expediente judicial, impidiendo la condena a Daniel. No obstante, en los últimos minutos de la película, observamos como Alicia realiza pequeños "actos subversivos" (Pagnoni Berns p. 290) ${ }^{11}$, para imponer su identidad individual de madre, sin realizar lo que se espera de ella dentro de las estructuras patriarcales. Ella ha tenido que enfrentarse con su propia moral y ha debido reevaluar sus decisiones. Así, Alicia le devuelve a su exnuera Marcela, el expediente judicial robado a su pedido, facilitando con esto la reapertura del juicio de violación e intento de homicidio, y la condena de su propio hijo. Asimismo, Alicia permite la revisión de la condena a Gladys en la apelación judicial, al prestar testimonio proporcionando la nueva información sobre la violación que sufrió esta de manos de su

\footnotetext{
${ }^{11}$ Pagnoni Berns analiza las películas Géminis (2005), Conversaciones con mamá (2004) y Las mantenidas sin sueños, (2005) como ejemplos de representaciones que pluralizan el concepto de maternidad por la complejidad de sus historias que impiden la reducción al modelo tradicional de madre (p. 281). Agrega que el cine actual de Argentina ofrece múltiples maternidades con un amplio espectro de puntos de vista.
} 
De crímenes de familia a crímenes de Estado. La figura de la madre en la lucha contra la violencia de género en Crímenes de familia (2020) y Las tres muertes de Marisela Escobedo (2020)

hijo Daniel resultando en el embarazo no reconocido, junto al constante abuso, opresión y amenazas de su parte.

En México, la representación cinematográfica de la mujer y de la madre se contrasta en dos ejes retóricos, el de la 'buena madre' y la 'mala mujer', inmortalizados en los melodramas de madres y de cabareteras, respectivamente. Estos establecieron por mucho tiempo una dicotomía en cuanto al rol de la mujer/madre. Fue hasta la entrada en escena de las directoras en que se dejó esta dicotomía represiva para dar paso a una pluralidad de representaciones sobre la madre y las mujeres. Fuera de la pantalla, a partir de la creciente violencia contra las mujeres en las que son violentadas en los espacios domésticos y público. De esta forma, la realidad del México de finales de siglo $\mathrm{XX}$, trajo más que nunca las figuras de "las desaparecidas" o "las muertas" y de la madre activista. Estas dos figuras han llegado a las pantallas por medio de documentales nacionales y transnacionales. Entre los documentales más representativos sobre estas figuras destacan Señorita extraviada (2001) de Lourdes Portillo; La batalla de las cruces (2005) de Patricia Ravelo y Rafael Bonilla; La carta (2009) de Rafael Bonilla; Blood Rising (2013) de Mark McLouhlin, entre otros. En estos documentales, el director, a través de diversos recursos narrativos, construye o reconstruye una visión y la voz de estas figuras. En el documental Las tres muertes de Marisela Escobedo, la construcción de una valiente madre y su transformación forman el ángulo principal. Marisela es una madre fuerte y determinada que no se conforma a la pasividad impuesta por los mandatos patriarcales, y va a enfrentar la búsqueda de su hija y posterior pedido de justicia, sin dudarlo. Luego de la desaparición de Rubí, Marisela se convierte en defensora de los derechos de su hija cuando expresa "si yo no estaba ahí, nadie iba a hacer nada por ella". También, logra después de casi dos meses que le reciban una denuncia judicial para abrir un caso por la desaparición de su hija; en su búsqueda por la verdad, ella también deviene en investigadora privada, deambulando por bares nocturnos y prostíbulos en la Ciudad de Juárez en busca de noticias de Rubí, y luego de la confesión del yerno, emprende la búsqueda del cuerpo de su hija, y en una de las entrevistas afirma su fortaleza al dejar en claro que "no iba a parar hasta que no la encontrara". 
Las transformaciones de Alicia y Marisela ponen no sólo en evidencia las falencias de la sociedad de Argentina y México, sino que son una respuesta directa a la violencia de género que enfrentan. Crímenes de familia muestra una Argentina en la cual es evidente las desigualdades derivadas de violencia estructural, a través de las experiencias de vida sufridas por Gladys durante su infancia y adolescencia debido a su condición socioeconómica y familiar que contrastan fuertemente con la situación de vida de Alicia. Mientras que en México se focaliza en develar las estructuras patriarcales que atraviesan diferentes sectores del gobierno y, en particular el sistema judicial y la policía. Mediante la historia de Marisela se denuncia que, en este país, la justicia no es igual para todos. Por ejemplo, la activista cuestiona fuertemente la rapidez con que fueron resueltos los casos de secuestro y desaparición de familiares de importantes figuras políticas como el gobernador del estado, César Duarte, y la ex procuradora de justicia, Patricia González. Mientras estos casos son resueltos rápida y eficientemente por las autoridades debido al perfil de los afectados, las familias comunes sin privilegio no gozan de esta eficacia para que los casos de sus familiares desaparecidos o asesinados sean resueltos o atendidos. Estos cambios en su postura tradicional de madres posibilitan la construcción de nuevas representaciones de lo materno desde que pluralizan las experiencias vividas a partir de la violencia de género y formulan mediante 'pequeños actos subversivos' estrategias para combatirlas. Este cambio en la perspectiva de las madres es puesto en escena por los directores mediante estrategias narrativas y fílmicas que presentan en las películas en análisis.

\section{Crímenes de familia: suspenso y violencia doméstica}

El suspenso es el hilo conductor en Crímenes de familia, y si bien la narrativa entrecruza la historia de tres madres, Alicia, Gladys y Marcela, indiscutiblemente se focaliza en las acciones de Alicia; y es a través de su perspectiva que el espectador se concientiza de la dimensión de la violencia de género. Esta película está basada en dos casos reales que ocurrieron en Argentina en el nuevo milenio, y que no recibieron una amplia cobertura mediática, según lo explica el director en la entrevista brindada en el sitio web del Ministerio de Cultura de Argentina. Schindel decide fusionar estos dos casos para que ocurran dentro de la misma familia y los ficcionaliza en la trama utilizando 
De crímenes de familia a crímenes de Estado. La figura de la madre en la lucha contra la violencia de género en Crímenes de familia (2020) y Las tres muertes de Marisela Escobedo (2020)

elementos de suspenso para acentuar el dramatismo de los eventos ${ }^{12}$. La película comienza con una escena central a la estructura narrativa, la cual se repite en el largometraje y es generadora de suspenso. La cámara fija a nivel de piso, muestra un pasillo oscuro con paredes de azulejos con una ventana en el lado izquierdo que deja entrever un hilo de luz azulado. Al final del estrecho pasillo se ve una puerta cerrada con una ventana pequeña en la parte superior que deja entrever una luz blanca. Esta escena se acompaña con unas notas tenebrosas y ominosas de piano, que funcionan de manera premonitoria, las que se entremezclan con sonidos de movimientos torpes detrás de la puerta. Finalmente, esta se abre y sale una joven caminando con dificultad hacia la cámara. Ella, vestida con un camisón blanco, avanza entre jadeos con movimientos lentos y se apoya en la pared. La escena dura menos de un minuto, y el espectador puede deducir que detrás de esa puerta ha ocurrido algo terrible; esta secuencia se convierte así en el misterio a descubrir en la historia porque no se presenta ninguna otra información ya que a continuación aparece el título de la película. Esta misma escena del pasillo oscuro se repite tres veces más durante la primera parte de la película; y en cada una de ellas el director proporciona un poco más información al espectador, incrementando el suspenso, por la falta de detalles. Por ejemplo, la segunda vez que se muestra esta escena en el minuto veinticuatro, se observa que es Gladys la joven que continúa caminando en el pasillo hasta salir del encuadre y es ahí cuando la cámara lentamente hace un acercamiento hacia el baño vacío para revelar sangre en el piso y los azulejos. La tercera vez que se presenta la secuencia descrita, Gladys camina de espalda entrando a cuadro hacia el baño, con un balde y trapeador en cada mano para limpiarlo. Finalmente, la última vez que se repite esta escena, Gladys ya al final del pasillo de espaldas, ingresa al baño y cierra la puerta, dejando al espectador imaginar sus acciones y movimientos dentro del baño. Es esta escena la que introduce el elemento de suspenso en Crímenes de familia, creando la incógnita en el espectador sobre la naturaleza del crimen que el título anuncia.

\footnotetext{
${ }^{12}$ Con relación a los casos en los que se ha inspirado, explica Schindel que "Cuando trabajo con hechos reales, documento muchísimo, investigo y esa es mi fuente de inspiración, de trabajo. Para esta película trabajé con dos casos puntuales que me impresionaron mucho, y que luego modifiqué para que transcurrieran en el marco de la misma familia".
}

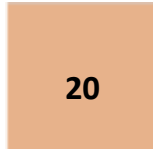

Cuadernos del CILHA n $34-2021$

ISSN 1515-6125 | EISSN 1852-9615

CC BY-NC 2.5 AR

http://revistas.uncu.edu.ar/ojs/index.php/cilha/ 
En un sentido general, el suspenso se define como una estrategia para mantener la atención o interés del espectador ya que se trata de un retraso en el cumplimiento y establecimiento de expectativas (Bordwell y Thompson, 2008 p. 57). Por su parte, Robert Yanal (1996) explica que, para crear suspenso, la narrativa no sólo retiene información, sino que también implica posibles resoluciones alternativas a la historia contada. Agrega que esta incertidumbre acerca del resultado es una condición indispensable, aunque no la única para crear suspenso. La escena descrita del pasillo es medular ya que introduce otra temporalidad. La primera, presenta anacrónicamente el crimen ocurrido en ese baño. La segunda temporalidad es el presente narrativo que se enfoca en dos juicios paralelamente, el de Gladys y el de Daniel. De Gladys al principio sólo sabemos que se despierta esposada en el hospital, luego la llevan al juzgado a tomar declaración, y por último a la cárcel. El caso judicial de Daniel es por violación e intento de homicidio de su exesposa Verónica. Además de estas dos temporalidades, Crímenes de familia presenta dos líneas narrativas que abarcan estos casos judiciales, el juicio a Daniel y el juicio a Gladys. Ambas líneas narrativas van unidas por la escena del pasillo que se convierte en el leitmotiv. El espectador debe dilucidar cuál es la razón por la que Gladys está siendo juzgada mientras que conoce claramente el motivo por el cual Daniel está siendo juzgado.

El espectador desconoce de qué se le acusa a Gladys hasta el minuto cincuenta y tres en el cual ambas temporalidades se unifican cuando el marido de Alicia luego de ser despertado por esta, que escuchó ruidos a la noche, se acerca al baño y descubre el homicidio. En este preciso momento se devela la razón del juicio, Gladys ha matado a su bebé recién nacido, asfixiándolo. Este embarazo y nacimiento sorprende tanto a Alicia y su marido como al espectador. Consecuentemente, el motivo por el que se la juzga se da a conocer: homicidio agravado por el vínculo. Esto es así porque en Argentina la figura del infanticidio fue derogada del código penal en la reforma de 1994. En este momento de la película, al unirse las dos temporalidades los elementos de suspenso utilizados dan paso a enfocarse en el drama de la violencia doméstica. Al espectador se lo confronta directamente con las elecciones de Alicia, cuestionables moralmente, como el pago de dinero para que el abogado haga desaparecer el expediente del juicio de Daniel. Esta decisión de Alicia causa la ruptura de su 
De crímenes de familia a crímenes de Estado. La figura de la madre en la lucha contra la violencia de género en Crímenes de familia (2020) y Las tres muertes de Marisela Escobedo (2020)

matrimonio, ya que su esposo no está de acuerdo con la continua sobreprotección de Alicia a su hijo Daniel. Ambos padres conocen bien el lado criminal de Daniel, por las anteriores estafas y desfalcos a los negocios o empresas en las que él trabajaba, y además saben de los problemas con la droga que tiene su hijo. En el juicio oral, Alicia no defiende a Gladys de la misma manera que lo hace con su hijo incondicionalmente, y esto se observa con claridad en el frío testimonio que brinda en tribunales. Dicho juicio culmina con la condena de Gladys a dieciocho años de prisión. La severidad de la pena es evidente ya que el tribunal no tuvo en cuenta las causas que predeterminaron el accionar criminal de Gladys, las cuales quedaron expuestas en el testimonio de la psicóloga durante el juicio que es su única defensora. Esta profesional explica en su testimonio que Gladys es semianalfabeta y presenta un leve retraso madurativo, por todo ello no estaba capacitada para entender la criminalidad de sus acciones ya que también negaba la existencia de su embarazo por un aparente trauma sufrido.

Ana Amado y Nora Domínguez (2004) consideran a la familia "como una categoría a un mismo tiempo discursiva, cultural, social y teórica" (15), y también la adoptan como "una herramienta crítica" que es clave para poder reflexionar sobre el presente y sus alternativas. En sentido similar, Ludmer (2002) al referirse a las temporalidades del presente, analiza las ficciones publicadas en los primeros años del siglo XXI manifestando su interés en "la organización familiar" ya que aparece como una figura frecuente en la cultura argentina del cambio de siglo. Así entiende que "la familia liga temporalidades y subjetividades en formas biológicas, afectivas, legales, simbólicas, económicas y políticas" (26). La familia como categoría y herramienta de crítica es esencial por lo que ella refleja de las tendencias sociales y culturales en Argentina. Es por lo que es imperativo estudiar la representación fílmica reciente de las nuevas familias. Evidentemente, la estructura familiar tradicional es central en la historia narrada en Crímenes de familia ya que dicha unidad es el escenario en el que se desarrollan las tensiones que ponen en evidencia la violencia de género y la violencia estructural. La familia en torno a la cual se estructura la trama -madre, padre e hijo- se presenta con evidentes problemas. En ese sentido, la construcción de la perspectiva de Alicia es la que ofrece una mirada innovadora, ya que primero se la muestra en su rol tradicional de madre abnegada, para luego abandonarlo. 
Aunque la película en estudio se enfoca en la perspectiva de Alicia, la madre tradicional; presenta a su vez una pluralidad de acercamientos a la maternidad. Esto lo hace a través de los otros dos personajes femeninos, las otras dos madres jóvenes que interactúan con Alicia. Por un lado, Marcela, la exnuera de Alicia, es la madre que lucha sin tregua por lograr su bienestar y el de su hijo. A pesar de ser víctima de la violencia de manos de Daniel en repetidas ocasiones, ella se rebela y recurre en busca de ayuda a las instituciones que le permiten acceder a las medidas judiciales que existen para protegerla. Esta joven madre ya ha obtenido una sentencia previa contra Daniel, al cual se lo condenó por la violencia que ejerció contra ella, si bien la pena fue de cumplimiento condicional, ella también ya ha logrado obtener una perimetral, una orden de restricción de acercamiento en contra su expareja. No obstante, las numerosas denuncias que hizo Marcela, no le dieron protección, sino hasta que Daniel la acuchilló por primera vez, lo que inició el juicio. Es evidente que este personaje es una madre rebelde que demanda la protección de sus derechos y protege su vida y la de su niño y la suya a toda costa. Por otro lado, Gladys es la 'mala madre' de acuerdo con la normatividad patriarcal, pero ha sido víctima de violencia estructural ya que tuvo una infancia muy sufrida y con abuso; y en la actualidad, si bien sus patrones la tratan con respeto y dignidad, cae víctima del hijo de estos, del cual recibe más abusos conectados al lugar de trabajo. Gladys casi no tiene la capacidad de criar o educar a su propio niño por sus evidentes problemas de aprendizaje, y es aquí donde se observa la cálida interacción entre su hijo con Alicia. Estas dos jóvenes madres son las que ayudan a Alicia a evolucionar en sus perspectivas. De su exnuera aprende que es importante rebelarse y luchar por sus derechos, y de Gladys aprende a tener en cuenta todas las condiciones el contexto que rodea y afectan a una madre. Alicia entiende, a través de lo sufrido por Gladys, que hay una razón o motivo detrás de la violencia. En este caso, el embarazo fue consecuencia de la violación y constante abuso de poder de su hijo Daniel. En estas manifestaciones de la violencia de género representadas en la película, se revelan las estructuras sistémicas relacionadas con la colonialidad del poder y de género mencionadas por Lugones, en las que sugiere que es indispensable historizar el sistema de género para remover del centro de la reflexión al sistema jerárquico y binario del patriarcado. 
De crímenes de familia a crímenes de Estado. La figura de la madre en la lucha contra la violencia de género en Crímenes de familia (2020) y Las tres muertes de Marisela Escobedo (2020)

En cuanto a Gladys, su historia tiene una evidente conexión con la leyenda de la llorona. Esta es una figura mítica de una mujer maldecida, por su acto de matar a sus hijos, a deambular llorando en un lugar. En opinión de Cristina Santos (2016), la leyenda de la Llorona presenta una partida de las expectativas socio culturales que refuerzan un código de conducta específico que solidifica una condena a una mujer que no se adapta a su lugar de madre en la familia o la sociedad (p. 300). Para Santos la figura de la "madre monstruosa" emerge dentro de la cultura dominantemente patriarcal que privilegia las construcciones de madre perfecta e imperfecta (p. 300), y no se adhiere a las expectativas de la madre ideal. Santos al referirse a los varios ejemplos de versiones actuales sobre el mito de la llorona, existen innumerables casos de estas madres malignas que cometen actos de locura hacia sus hijos por las imposibles circunstancias sociales en las que se encuentran (p. 305). En el caso del crimen cometido por Gladys, el testimonio brindado por la licenciada en psicólogía, especializada en infanticidio, brinda el único punto de vista que tiene en cuenta el contexto previo al acto. En su evaluación de Gladys, la psicóloga aclara que este tipo de hechos ocurren en casos de angustia extrema, como en el caso de Gladys. Expresa también que la madre no recuerda lo que ha sucedido, porque la madre se convence de que el embarazo no existe, por lo que ese embarazo nunca va a suceder, y agrega que este es un común denominador con otros casos de infanticidio. El valor pedagógico de la película reside en que viene a desmitificar el mito de la 'mala madre', abriendo la posibilidad de encontrar diferentes interpretaciones al tener en cuenta el contexto social, económico que ha condicionado la conducta maternal de estas 'malas madres'. Tal como lo explica la psicóloga en su testimonio, Gladys nació y vivió en condiciones de extrema pobreza, sufrió abuso intrafamiliar por lo que es incapaz de hacer frente a la maternidad, incluso aclara que al primer hijo lo ha criado la patrona de Gladys, Alicia. Finalmente, la psicóloga expone que existe la posibilidad de que este embarazo haya sido el fruto de una violación.

El desmoronamiento de la familia tradicional a lo largo de la película, y la consecuente formación de una unidad familiar alternativa, con Marcela y Gladys, refleja el cambio de Alicia y su aprendizaje. La intersección de estas tres madres exhibe el amplio espectro de la experiencia de ser madre que es afectada directamente por las diferentes realidades que cada una vive. Aunque se presentan las tres madres, la

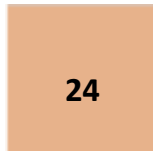

Cuadernos del CILHA n $34-2021$

ISSN 1515-6125 | EISSN 1852-9615

CC BY-NC 2.5 AR

http://revistas.uncu.edu.ar/ojs/index.php/cilha/ 
película construye la perspectiva de la madre tradicional, y con el cambio observado por ella, presenta la sugerencia de que es necesaria la evolución de este rol. En la sociedad de Argentina en pleno siglo XXI se sugiere que la madre abnegada y tradicional, dentro de la normativa patriarcal, no tiene cabida, y necesita adaptarse al contexto actual para estar de acuerdo con los tiempos que transcurren. Es indudable que Crímenes de familia invita al espectador a reflexionar sobre la maternidad en la sociedad argentina que transita la segunda década del nuevo siglo. En ese sentido, la representación cinematográfica de la maternidad no solo muestra las multiplicidades actuales de este rol, sino que también retroalimentan la cultura afectando actitudes e ideas acerca de estos roles; a la vez que exhiben nuevas relaciones y los potenciales de mujer y madre. Finalmente, Crímenes de familia lleva al centro la reflexión sobre la creación de una comunidad de apoyo invitando a reflexionar sobre la sororidad creada entre las tres madres en esta historia. Como ya se ha explicado, Segato propone una contra-pedagogía de la crueldad con el objetivo de crear y nutrir relaciones que enseñen a valorar a las personas como personas. En el testimonio brindado por la psicología, se observa esta contra pedagogía de la crueldad porque, en este testimonio se contextualiza las acciones de Gladys, y se la humaniza en relación con todos los problemas y abusos sistémicos que ha sufrido desde niña.

Denuncia, contrainformación y violencia sistémica: Las tres muertes de Marisela Escobedo

Como ha identificado Julienne Burton (1990) el documental en Latinoamérica se ha caracterizado por ser un instrumento de transformación política y social ya que además de representar un recurso de contra-información, da voz a individuos y grupos ignorados por los medios hegemónicos (p.6). Burton señala que históricamente, sobre todo a partir del movimiento del Cine Nuevo, la producción documental en Latinoamérica se ha caracterizado por un compromiso con la transformación política de su entorno, en la que muchos cineastas, explícita o tácitamente, han fungido a través de sus producciones como defensores, acusadores, agitadores y disidentes (p.27). Además, menciona que desde la incepción del movimiento de documental social en los años cincuenta del siglo $X X$, los cineastas latinoamericanos han expandido 
De crímenes de familia a crímenes de Estado. La figura de la madre en la lucha contra la violencia de género en Crímenes de familia (2020) y Las tres muertes de Marisela Escobedo (2020)

constantemente el concepto de este al dar prioridad, entre otros aspectos, a la investigación sobre la exposición, a enfocarse en el proceso más que en análisis, y a "poetizar" más que brindar información factual (p. 50). De esta manera, ubicamos en la tradición del documental social Las tres muertes de Marisela Escobedo, ya que a través de una cuidadosa investigación periodista a cargo de la periodista Karla Casillas Bermúdez se expone y denuncia la intrincada red de factores estructurales y sociopolíticos que produce la violencia en contra las mujeres en México. Cumpliendo de esta manera con el objetivo de dar voz a las víctimas de violencia, ya que a través de la historia de Marisela Escobedo y su hija Rubí se representan las historias ignoradas de miles de mujeres víctimas de la violencia en México ${ }^{13}$. El escenario de la tragedia de Marisela Escobedo es Ciudad Juárez. Esto es particularmente significativo, ya que en México este sitio ha adquirido un carácter emblemático y polisémico en cuanto a la violencia de género se refiere. Así, esta ciudad se ha convertido en el referente de la violencia extrema contra las mujeres mexicanas por el alto número de víctimas de feminicidio y mujeres desaparecidas en su área metropolitana. Además, es el símbolo de la indiferencia e incapacidad de un estado patriarcal en proveer justicia a las víctimas de esta violencia ${ }^{14}$. Igualmente, representa el lugar de resistencia y rechazo frente a esta problemática. Esta falta de justicia en torno a los casos de feminicidio ha provocado diversas respuestas de distintos sectores como organizaciones gubernamentales y no gubernamentales (nacionales e internacionales), medios de comunicación, grupos académicos, y de la sociedad civil. Entre las voces que conforman el reclamo de justicia en la sociedad civil, se encuentran el de otras mujeres y especialmente, la de las madres de las víctimas de feminicidio.

Nelson Arteaga Botello y Jimena Valdés Figueroa (2010) señalan que los feminicidios ocurridos en Ciudad Juárez no son un mero fenómeno de esta urbe, sino que representan un escenario generalizado en todo el país (p. 15). Establecen que esta

\footnotetext{
${ }^{13}$ Por ejemplo, el periódico El Universal indica que del 1 de enero de 2019 al 30 de abril del mismo año se cometieron 1.199 feminicidios y homicidios dolosos de mujeres, lo que representa que cada día fueron asesinadas 10 mujeres.

14 El portal Animal Político señala que en México entre 2014 y 2018 alrededor de 145 mil víctimas (principalmente mujeres) de presuntas violaciones y abusos sexuales presentaron una denuncia formal en contra de sus agresores ante el Ministerio Público. Sin embargo, solo cinco de cada 100 de estos casos logran obtener una sentencia para el agresor.
}

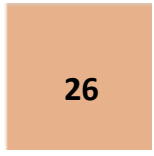

Cuadernos del CILHA n $34-2021$

ISSN 1515-6125 | EISSN 1852-9615

CC BY-NC 2.5 AR

http://revistas.uncu.edu.ar/ojs/index.php/cilha/ 
violencia es "el resultado de una masculinidad trastocada" por una crisis socioeconómica generalizada y a nuevas "formas de construcción como sujetos de las mujeres" (p. 16). En parte, se ha señalado que el modelo económico neoliberal en Latinoamérica provocó, entre otras cosas, la disminución los programas de ayuda social enfocados a promover en un bienestar público y garantizar los derechos de la ciudadanía como el acceso al trabajo, seguridad pública, servicios sociales y civiles (Rosa-Linda Fregoso, 2009, p.213). Por ejemplo, en el caso particular de Ciudad Juárez, las empresas maquiladoras que se instalaron en la región a partir de la firma en 1994 del Tratado de Libre Comercio entre Canadá, México y Estados Unidos, privilegiaron la mano de obra femenina, desplazando con esto a la masculina ${ }^{15}$. Aunado a esto, la inversión de la ciudad en la infraestructura urbana y servicios sociales ha sido mínima, favoreciendo en cambio la protección de los derechos de la propiedad privada nacional y transnacional. En este sentido, el feminicidio y otras formas de violencia son una forma de hacer visible el dominio patriarcal del estado y de los hombres sobre las mujeres ante la incapacidad de asimilar la pérdida de poder sobre ellas cuando éstas alcanzan una independencia económica, o bien, exigen sus derechos civiles y sociales. Es bajo este contexto en que Las tres muertes de Marisela Escobedo desarrolla la historia particular de una de estas madres. De esta forma, la historia de Marisela y Rubí deja de ser una estadística más de feminicidio en Ciudad Juárez para convertirse en una historia personal que busca humanizar a las víctimas al proporcionar una dimensión personal. Con esto el documental busca sensibilizar al espectador a través del dolor, la impotencia, y la resiliencia de una madre en busca de justicia.

Las activistas conocidas como "Las madres de Chihuahua", haciendo eco a las Madres de la Plaza de Mayo de Argentina, centran sus demandas en la verdad y la justicia. De acuerdo con Elva Orozco Mendoza (2019) el activismo maternal en el norte de México se ha convertido en una lucha constante para transformar, las estructuras y las normas de género que producen las condiciones para una violencia extrema (p. 214). Orozco Mendoza, señala que en Chihuahua cuando una mujer o niña es reportada como

${ }^{15}$ Ciudad Juárez se transformó en el emblema de la globalización económica y del neoliberalismo con la entrada en vigor del Tratado del Libre Comercio (TLC) entre Canadá, Estados Unidos y México.

Cuadernos del CILHA n $34-2021$

27

ISSN 1515-6125 | EISSN 1852-9615

CC BY-NC 2.5 AR

http://revistas.uncu.edu.ar/ojs/index.php/cilha/ 
De crímenes de familia a crímenes de Estado. La figura de la madre en la lucha contra la violencia de género en Crímenes de familia (2020) y Las tres muertes de Marisela Escobedo (2020)

desaparecida o su cuerpo sin vida aparece raramente esto es considerado como evidencia que un crimen se ha cometido en su contra, por el contrario, para las autoridades esto es una muestra de que criminalidad o "mala conducta" de la víctima (p. 218). Así, mientras que las autoridades han fallado en plan de acción eficiente y confiable para investigar los crímenes y encontrar a los responsables, son las familias y sobre todo las madres las que se han dado a la tarea de hacer este trabajo, como es mostrado en el caso de Marisela. El documental muestra cómo, con sus propios recursos, Marisela logra primeramente, encontrar a un testigo que le esclarezca lo que sucedió con Rubí. Posteriormente, tras un trabajo de investigación, localiza en otro estado de la república a la expareja de Rubí y su presunto asesino, Sergio Rafael Barraza. Finalmente, tras la liberación de Barraza, vuelve a localizarlo esta vez poniendo su vida en peligro tras la asociación de este con el cártel de los Zetas ${ }^{16}$. Estas acciones son vistas como actos maternales subversivos en contra de las autoridades y del sistema judicial y penal al evidenciar sus fallas e indolencia ante la violencia en contra de las mujeres.

Como hemos establecido, este documental sensibiliza al espectador sobre las víctimas de feminicidio al enfocarse en un caso en específico. El director Pérez Osorio busca establecer con el espectador una conexión a un nivel más emocional, al enfocarse en el dolor de una madre por la pérdida violenta de su hija. Pérez Osorio lleva de la mano al espectador para que acompañe a Marisela en cada paso de su periplo por las emociones que ésta experimenta, como dolor, frustración y enojo. Esto provoca además hacia el final del documental que el espectador no solo empatice con Marisela y por añadidura los otros casos de violencia, sino que genere admiración ante la resiliencia de las madres y familiares de las víctimas. Con esto, establecemos que el documental funciona como una herramienta contra la pedagogía de la crueldad al sensibilizar al espectador. Para lograr esto Pérez Osorio hace uso de una serie de elementos visuales y auditivos para dramatizar e ilustrar la historia de Marisela y Rubí. Un compendio de los recursos que el director usa a lo largo del documental es mostrado en la primera secuencia después de los títulos iniciales. En esta secuencia se muestra un collage de diferentes elementos que ilustran lo que se va a mostrar en el documental. Predominan los videos caseros de la familia resaltando imágenes de la infancia de Rubí; parajes desolados de la ciudad

16 También conocidos como cártel de los Zetas, fue una organización criminal mexicana conocida por actividades terroristas, de extorsión, secuestros, homicidas, tráfico de personas y tráfico de drogas.

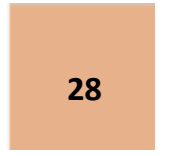

Cuadernos del CILHA n $34-2021$

ISSN 1515-6125 | EISSN 1852-9615

CC BY-NC 2.5 AR

http://revistas.uncu.edu.ar/ojs/index.php/cilha/ 
donde más adelante el espectador se enterará que son los lugares donde son enterrados los cuerpos de las niñas y mujeres; posters pidiendo información de las mujeres desaparecidas; y audios e imágenes de los medios de comunicación informando sobre los feminicidios. Uno de estos audios, montado sobre una imagen de la ciudad, informa: "Ciudad Juárez fue catalogada como la ciudad más peligrosa del mundo. También es el lugar donde ser mujer es una sentencia de muerte". Estos recursos proporcionan una idea del tono dramático que tendrá la historia.

La sensación fúnebre e incluso poética del documental, se da en el título de este y en las imágenes de transición entre entrevistas y recreaciones usadas a lo largo del documental. Estas imágenes de transición además de proveer un descanso al espectador entre las emociones desplegadas por Marisela y su familia, brindan un espacio para que el espectador pueda asimilar el contenido de las entrevistas acompañado de imágenes que crean una atmósfera emocional. Por ejemplo, en las secuencias de transición destacan el paisaje urbano desértico y lotes baldíos de Ciudad Juárez, que remiten a la desolación de la madre, el abandono de las autoridades, y que representan la tumba de Rubí y de muchas otras víctimas de violencia. Algunas de las secuencias son tomadas desde drones que amplifican la vastedad del desierto y por lo tanto la gravedad del problema. A la par de las imágenes del paisaje, en las secuencias de transición sobresalen las cruces rosas y posters alrededor de la ciudad de las mujeres asesinadas o desaparecidas. Rosa-Linda Fregoso (2009) apunta que la cruz da una presencia a las muertas ya que "por sí misma es un indicador físico de la memoria; personaliza y materializa a las víctimas de los feminicidios [...]" (p. 229). Este mismo efecto producen los posters que buscan indagar el paradero de una mujer o niña desaparecida. Las cruces y los posters obligan a los espectadores a hacer una pausa y reconocer en ellos las vidas perdidas de las víctimas.

El ambiente fúnebre construido en el documental es acompañado en algunas partes por una estilística de suspenso propia de una historia de detectives donde hay que resolver un misterio o crimen. Dicha estilística se construye principalmente en los segmentos del documental que aborda el rol de Marisela como detective del caso de su hija. Esta atmósfera de suspenso ayuda a narrar las acciones realizadas por Marisela 
De crímenes de familia a crímenes de Estado. La figura de la madre en la lucha contra la violencia de género en Crímenes de familia (2020) y Las tres muertes de Marisela Escobedo (2020)

y su hijo Juan Manuel para encontrar en primer lugar a Rubí y después a Sergio Barraza. Además, la estilística de suspenso sirve para involucrar al espectador con los eventos narrados por Marisela y mantenerlo expectante sobre dónde, cómo y cuándo se va a encontrar a Rubí o a capturar a Barraza. La primera vez que se presenta este recurso es en la búsqueda del paradero de Rubí. Por medio de una toma nocturna aérea se presenta una panorámica de la ciudad en la que se despliega un texto en blanco señalando la fecha, "Diciembre 2008". La toma panorámica y la fecha ubican al espectador en el tiempo y el espacio donde ocurren los eventos que se narran después de estas tomas. Sobre esta imagen escuchamos la voz superpuesta de Marisela señalando que "Inmediatamente empiezo yo, como madre de ella, las indagatorias. Se me empiezan a encender luces de alarma de que a ella le había pasado algo". Esto es en referencia a la desaparición de Barraza y sus sospechas sobre la veracidad de que Rubí había huido con otro hombre. Después del audio de Marisela, hay un corte abrupto a una pantalla con fondo negro. Esta transición crea incertidumbre y tensión sobre el paradero y destino de Rubí. La siguiente imagen muestra, usando un efecto de cámara lenta, tomas nocturnas de las calles de Ciudad Juárez desde el interior de un automóvil simulando una subjetiva de Marisela o Juan Manuel manejando en búsqueda de Rubí. Las tomas subjetivas se intercalan con un plano detalle del autoestéreo sintonizado en las noticias donde escuchamos al locutor hablar sobre el clima de violencia que se vive en la ciudad ocasionado por el crimen organizado. El audio aborda la cuestión de la trata de personas generada por el crimen organizado, lo cual representa uno de los temores de Marisela sobre el destino de su hija. Esta tensión es reforzada con una música extradiegética que usa texturas electrónicas con tonos graves y ritmo lento. Las tomas subjetivas desde el auto continúan y se intercalan imágenes de ciertas calles y lugares de la ciudad, como bares y prostíbulos. La voz superpuesta de Juan Manuel narra la búsqueda incansable de Rubí en estos lugares, mientras un montaje de planos detalles e imágenes desenfocadas de la vida nocturna de la ciudad generan una atmósfera de ambigüedad y desorientación. La secuencia expresa la impotencia y desesperación de Marisela y Juan Manuel, así como el misterio y suspenso por encontrar a Rubí en estos lugares. Estos elementos de tensión y suspenso representan otro de los recursos usados por Pérez Osorio para mantener la atención e involucrar emocionalmente al espectador brindando información adicional sobre la generalizada violencia contra las mujeres. 
El director Pérez Osorio utiliza una variedad de recursos narrativos, sin embargo, es la construcción de la voz de Marisela a través de la articulación de varias entrevistas, lo que proporciona un tono emocional, informativo y de denuncia. Esta articulación crea la sensación en el espectador que la narradora del documental es Marisela, y no una construcción manipulada de su testimonio en la isla de edición. La primera imagen con la que abre el documental es un claro ejemplo de esto. En un primer plano vemos a Marisela bajo un fondo blanco sentada declarando directamente a la cámara:

Buenas tardes. Mi nombre es Marisela Escobedo Ortiz. Madre de Rubí Marisol Fraire Escobedo. Y le he perdido el miedo a todo. Le he perdido el miedo a la muerte, que es lo peor que me podría suceder. He enfrentado a las autoridades. He enfrentado al Gobernador. He enfrentado a quien se me ha puesto enfrente. Y quiero que mi hija donde quiera que esté que sepa que la amo y que no voy a dejar de luchar hasta que no se le haga justicia.

En esta toma, Marisela se posiciona ante todo como una madre, específicamente la de Rubí. Después, informa al espectador de los actos subversivos que como madre ha realizado en búsqueda de justicia para su hija. La manera en que se presenta Marisela, posicionándose primero, se asemeja al estilo usado en la tradición del género testimonial al estilo de otras activistas como Rigoberta Menchú y Domitila Barrios. En su presentación se posiciona también como luchadora social que desafía al sistema que ha tratado de silenciarla, no obstante, es su amor de madre lo que mueve todo su accionar. Al final del documental el espectador entiende que, aunque es una crónica sobre impunidad, injusticia y violencia, es finalmente una historia de amor de una madre; tal como lo señala la representante legal de la familia: "Esta es una historia de amor que además es la historia de muchos padres, muchos hermanos, hermanas, hijos e hijas que estamos viviendo actualmente".

En la primera parte del documental, Marisela aparece continuamente como protagonista de su historia. A través de las entrevistas conocemos distintos aspectos de su vida familiar antes de la desaparición de Rubí y durante la búsqueda de ésta. Por ejemplo, conocemos por Marisela la intrincada relación familiar con Rubí y su pareja, 
De crímenes de familia a crímenes de Estado. La figura de la madre en la lucha contra la violencia de género en Crímenes de familia (2020) y Las tres muertes de Marisela Escobedo (2020)

así como la angustiante pesquisa para encontrar a su hija como a su exyerno. La presencia y voz de Marisela además de ser constantes y directas por medio de sus testimonios se extienden a otros elementos narrativos como los videos caseros, fotografías familiares y material audiovisual de archivo. Así, literalmente, la voz de Marisela acompaña al espectador. Esto sumado al material familiar-videos y fotos-dan una dimensión más humana a Marisela, acercándola al espectador más como una madre que como una activista. Sin embargo, son las imágenes de la reacción de Marisela ante el veredicto del juicio donde es absuelto el yerno por la desaparición y presunto asesinato de su hija, las que muestran la vulnerabilidad de la activista. Antes de la muerte de Marisela, en los sucesos donde no existen registros de sus comentarios, el director articula la presencia de ésta por medio de entrevistas de las personas más cercanas a ésta, como los testimonios de sus hijos, su hermana, sus amigas y sus representantes legales. Al principio, estas entrevistas son usadas para acompañar las narraciones de Marisela y complementar su historia. Después del asesinato de la activista, estos testimonios se enfocan en recordar y recuperar el legado de Marisela como madre, amiga y activista. El director aprovecha las entrevistas y recuerdos de los conocidos de la activista para motivar la continuación de su trabajo. Las imágenes de Marisela después de su muerte, a diferencia de las de Rubí que solo queda como un recuerdo doloroso, preservan su voz donde sus ideas, declaraciones y proclamas se continúan escuchando.

El destino de Rubí no es solo es un destino compartido con otras mujeres mexicanas, también es un destino que han sufrido otras mujeres en el continente. Al respecto Fregoso (2009) señala que "los cuerpos violados, dejados en áreas públicas, desfigurados, desmembrados" de las mujeres en Ciudad Juárez se asemejan a los encontrados en Argentina, Guatemala, El Salvador en cuanto al "sadismo, saña y absoluta impunidad" (p. 210). En este sentido, el documental sobre Marisela Escobedo es una historia que reverbera en toda Latinoamérica y más allá.

\section{Construyendo sororidad y comunidad}

Crímenes de familia y Las tres muertes de Marisela Escobedo muestran al final de cada una, un importante mensaje de unidad entre mujeres. Estos mensajes van dirigidos abiertamente al espectador, interpelándolo a reflexionar sobre las causas y 
consecuencias de la violencia de género en las historias que termina de ver. Al mismo tiempo, ambas obras exhortan a la acción ya sea con pequeños o grandes actos de subversión como marchar por los derechos o simplemente informarse sobre la violencia de género. Asimismo, estos se acentúan en la construcción de la perspectiva de ambas madres, Alicia y Marisela, las que evolucionan en su rol materno para adaptarse a las circunstancias extremas que enfrentan, derivadas de la violencia de género. Sus historias son similares a otras que sufren muchísimas mujeres en México y Argentina.

Las tres muertes de Marisela Escobedo da indicios de diferentes niveles de sororidad que germinan a pesar del escenario de violencia generalizada en México. Por ejemplo, en la primera parte del documental cuando Marisela está en busca de pistas para saber lo que sucedió con su hija, es contactada por un conocido de su yerno. Éste le relata que el hermano de Sergio le dice a un grupo de amigos: "Mi hermano se quebró a su ruca, Rubí". Posteriormente, es el mismo Sergio que le confiesa a este grupo, "Sí la maté. Fuimos a tirarla a las marraneras. La metí en un tambo de basura y la quemé". Cuando Marisela le pregunta al testigo por qué decidió contactarla, el joven le cuenta que su hermano fue asesinado y que por esta razón su madre lo exhortó a que revelara lo que sabía. En este sentido, gracias al dolor y la solidaridad de otra madre, Marisela pudo obtener la información que aclarara la desaparición de Rubí. Después de la tercera muerte de Marisela (su muerte física), además de exponer la corrupción de las instituciones gubernamentales y su colusión con el crimen organizado y el narcotráfico, el documental se enfoca en la sororidad y concientización de las mexicanas. Las últimas imágenes del documental muestran la tradicional marcha masiva llevada a cabo el 8 de marzo de 2020 en el zócalo de la Ciudad de México con motivo de la conmemoración del Día Internacional de la Mujer, encabezada por madres de mujeres asesinadas o desaparecidas, mujeres víctimas de la violencia. En el año 2020, además de la marcha en la que participaron 80 mil mujeres, se convocó a un paro laboral masivo con el fin presionar al gobierno a tomar acciones ante la ola desmedida de violencia en el país, lo que simbolizó, sin lugar a duda, la unión de las mujeres más importante del México del siglo XXI. 
De crímenes de familia a crímenes de Estado. La figura de la madre en la lucha contra la violencia de género en Crímenes de familia (2020) y Las tres muertes de Marisela Escobedo (2020)

En los créditos finales, el documental cierra con la Canción sin miedo compuesto por la cantautora Vivir Quintanar que se ha convertido, desde el 2020, en el himno de las mujeres mexicanas. Bajo un fondo negro se brinda información sobre el problema de violencia en contra de las mujeres, y la corrupción de la esfera política. Se informa sobre la detención del entonces gobernador de Chihuahua Cesar Duarte por malversación de recursos públicos; y se enfatizan las cifras de la violencia en el país, "En México, un promedio de 10 mujeres es asesinada cada día. 97\% de los feminicidios quedan impunes". Al mismo tiempo que se proporcionan los datos la canción brinda un panorama del problema e increpa a la autoridad máxima del país a responder por estas muertes:

A cada minuto, de cada semana

Nos roban amigas, nos matan hermanas

Destrozan sus cuerpos, los desaparecen

No olvide sus nombres, por favor, señor presidente

Al igual que el documental, la canción nombra los casos emblemáticos de violencia en México tanto para recordar sus nombres como para corporeizar las víctimas en cada interpretación de la canción:

Soy Claudia, soy Esther y soy Teresa

Soy Ingrid, soy Rubí, soy Marisela

Soy la niña que subiste por la fuerza

Soy la madre que ahora llora por sus muertas

Finalmente, la canción exhorta a la solidaridad, toma conciencia sobre la magnitud de la violencia y hace un llamado a la acción: "Cantamos sin miedo, pedimos justicia, 
Gritamos por cada desaparecida, Que resuene fuerte “iNos queremos vivas!”, Que caiga con fuerza el feminicida".

Por su parte, en Crímenes de familia, el tema de la sororidad se desarrolla a través del entendimiento de los contextos y condiciones de las tres madres que presenta la historia. Mediante la línea narrativa del juicio llevado a cabo contra Gladys, presenta un mensaje claro: es indispensable tener en cuenta todas las circunstancias que confluyeron en la vida de Gladys que la llevaron a cometer ese crimen. En lugar de convertirla en la 'madre monstruo', como se esperaría tradicionalmente al responder a las estructuras patriarcales, la película nos ofrece otra alternativa. Schindel nos da la posibilidad de humanizar a este personaje, brindándonos información sobre lo que ha sufrido desde muy niña, una vida dura de abandono, abuso y falta de afecto; como también de oportunidades para mejorar su situación. Esta información se proporciona al espectador en la entrevista que Gladys tiene con la psicóloga, y en el testimonio que dicha profesional brinda en el juicio, acerca de la condición psicológica de negación del embarazo. Gladys toma la palabra al final del juicio para pedir a la corte que le otorgue la tenencia de su hijo Santi a Alicia, y también le pide perdón a ella por lo que ha sufrido a consecuencia de este juicio y finalmente le dice la ve como a una madre ${ }^{17}$. La intención de la película queda aún más en evidencia al final de la misma, cuando en la pantalla, luego de la última escena, y con el fondo en negro, se reproducen uno a uno los versos del poema titulado "La infanticida Marie Farrar", de Bertolt Bretch. Al espectador se lo invita a reflexionar seriamente sobre la historia que ha visto, al presentársele los siguientes versos:

Con sus últimas fuerzas, se arrastró hasta el retrete

y allí, sin más vueltas, parió hacia el amanecer.

Dice que entonces se sintió muy confusa, luego,

\footnotetext{
${ }^{17}$ En esta escena Gladys expresa que “No sé lo que me paso, solo Dios sabe de mi... se que mi vida no importa, está perdida, pero la de Santi sí importa. Él tiene que tener una vida mejor que la mía...".
} 
De crímenes de familia a crímenes de Estado. La figura de la madre en la lucha contra la violencia de género en Crímenes de familia (2020) y Las tres muertes de Marisela Escobedo (2020)

congelada, porque en el baño de servicio entra la nieve,

apenas tuvo fuerzas para alzar al niño.

En cuanto a ustedes, les ruego, se abstengan de juzgar.

Pues toda criatura necesita ayuda de todas las demás.

Indiscutiblemente, el mensaje que se ofrece a los espectadores es que es esencial entender el contexto y las circunstancias en las que ocurre el homicidio agravado por el vínculo, del que se la acusa a Gladys. En este juicio ella recibe una pena de dieciocho años de prisión. Es importante mencionar que una de las últimas escenas es la apelación a la sentencia contra Gladys, presentada por Alicia con la ayuda de la psicóloga. Esta apelación es posible gracias a la nueva información que brinda Alicia con relación al modo en que Gladys quedó embarazada por la violación de Daniel, y que ella desconocía. Gladys le agradece a Alicia, y le cuenta que Daniel la amenazó de muerte a ella y a Santi. Se hace imposible obviar el hecho de que este personaje es víctima de repetidas violaciones por parte Daniel en la casa de su patrona. A su vez, Gladys es un claro ejemplo de los efectos de la endémica pobreza y violencia estructural a la que ha sido sometida durante su vida.

Tan importante como entender el contexto de vida de Gladys que la llevó hasta ese momento del crimen, es el otro mensaje que ofrece el filme: la creación de sororidad entre mujeres. Dicha unidad se presenta en Crímenes de familia en los últimos minutos de la película, entre las tres madres. Alicia, Marcela y Gladys crean una pequeña comunidad para apoyarse y salir adelante juntas de estas circunstancias de opresión. Alicia queda a cargo del hijo de Gladys, Santi, mientras ella está en la cárcel, y el espectador observa como Alicia lleva al niño de visita a la cárcel para que pueda pasar tiempo con su madre. Más tarde, Alicia prepara una torta con Santi, y llegan a celebrar el cumpleaños de su nieto, en la casa de su exnuera. Esta nueva unidad familiar es una comunidad de afecto y apoyo, surgida como consecuencia de los efectos negativos de la violencia de género. No obstante, el final es esperanzador ya que se observa una reciprocidad entre estas tres madres que ahora comparten sus vidas persiguiendo crear una comunidad de apoyo mutuo y ayuda entre ellas.

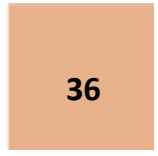

Cuadernos del CILHA n $34-2021$

ISSN 1515-6125 | EISSN 1852-9615

CC BY-NC 2.5 AR

http://revistas.uncu.edu.ar/ojs/index.php/cilha/ 
Como ya se ha mencionado, Netflix se ha posicionado como una empresa multinacional, sin embargo, parte de su éxito ha consistido en ofrecer contenido regional específico en su biblioteca para conseguir proximidad cultural con sus mercados $^{18}$. En ese sentido, Cornelio-Marí señala que el panorama de la producción original para México Netflix ha comisionado contenido de distintos géneros, como son la comedia, el drama, el documental y los reality shows (p. 16). La autora identifica que entre los temas que prevalecen en estas producciones originales destacan: el tráfico de narcóticos (EI Chapo, 2017), la política mexicana (Historia de un Crimen: Colosio, 2019), el fútbol (Club de Cuervos, 2017;), la música (Luis Miguel: La serie, 2018) y las dinámicas familiares (La casa de las Flores, 2018). En cuanto a la producción argentina, aunque menor comparada con la mexicana, podemos señalar que sigue la misma tendencia que México en cuanto a géneros sobre fútbol y deportes (River, el más grande siempre, 2019), música (Go! Vive tu manera, 2019), y dinámicas familiares (Edha, 2018). La elección de producción y distribución por medio de Netflix de las películas analizadas en este artículo responde a la urgencia de representar la violencia de género en las sociedades de México y Argentina, abriendo a debate las condiciones estructurales en las cuales se produce y visibilizándolas, a la vez.

Desde luego, hay temas específicos que corresponden a cada país como la problemática del narcotráfico en México, por ejemplo. Estas coincidencias en temáticas, géneros, y un lenguaje en común, produce una "comunidad" que, aunque imaginada siguiendo la idea de Benedict Anderson (2006), puede desarrollar un sentido de urgencia ante ciertos temas comunes a nivel regional como el caso de la violencia contra las mujeres. Este es el tema central en las dos películas analizadas y aunque está ubicado en contextos distintos, presenta los mismos retos. Uno de estos es reconocer y concientizar al espectador sobre el hecho que esta problemática es tan generalizada que no es ajena para ninguna mujer o niña de la región. Ambas producciones, no deben

18 En Latinoamérica esto se ve reflejado con la adquisición de los derechos de contenido producido por proveedores regionales como por ejemplo El Trece, Telefe, y TV pública en el caso de Argentina; y Canal 11, Televisa y TV Azteca en el caso de México. Sumado a esto, el contenido para Latinoamérica se enriqueció con las producciones originales de Netflix, siendo Club de Cuervos (2015) en México y 3\% (2016) en Brasil las primeras (Baladrón y Rivero, p. 118; Cornelio-Marí, p. 12).

Cuadernos del CILHA n $34-2021$ 
De crímenes de familia a crímenes de Estado. La figura de la madre en la lucha contra la violencia de género en Crímenes de familia (2020) y Las tres muertes de Marisela Escobedo (2020)

separarse de la movilización femenina en la región que ha creado una comunidad más allá de las fronteras, con movimientos como "Vivas nos queremos", "Ni una más", "Ni una menos" o himnos de protesta como la performance participativa del colectivo chileno Latesis "Un violador en tu camino" (2019) o "Canción sin miedo" de Quintanar.

\section{A modo de conclusión}

En este ensayo analizamos la centralidad otorgada a dos protagonistas madres, Alicia y Marisela, prestando particular atención a la perspectiva que brindan en Crímenes de familia y en Las tres muertes de Marisela Escobedo en relación con la violencia de género. Nos centramos en la evolución de ambas madres protagonistas para enfocarnos en sus transformaciones motivadas al ser afectadas directamente por la violencia de género. Explicamos que Alicia y Marisela dejan de ser madres tradicionales para convertirse en aliada la primera y activista la segunda; y con esto sostuvimos que ellas desafían y cuestionan las estructuras patriarcales que les asignan un rol pasivo y apolítico a las mujeres. Explicamos que los directores Schindel y Pérez Osorio posicionan a la madre en el centro de sus narrativas, ya que a través de ellas se expone la brutal realidad de violencia en contra de las mujeres que viven las sociedades de Argentina y México en la segunda década del siglo XXI. Nuestro análisis se ha enfocado en el estudio de las estrategias fílmicas utilizadas en ambos formatos (ficción y documental) para representar la figura de la madre. En estas dos películas los directores destacan los actos subversivos de sus protagonistas que desafían las normativas patriarcales asignadas en un rol pasivo de madre tradicional. Estas obras se inspiran de la experiencia materna de casos reales en Argentina y México y la redimensionan a través de la representación fílmica, abriendo la mirada hacia la maternidad para ofrecer una multiplicidad en la forma de vivir y ejercer la maternidad. A su vez, las películas reflejan cuestiones de violencia estructural porque las mujeres violentadas -Marcela, Gladys y Rubí- pertenecen a la clase socio económica trabajadora, y al mismo tiempo resaltan el privilegio de mujeres de clase media alta, como Alicia y Patricia, la ex procuradora de justicia de Chihuahua.

Sostuvimos que, al seleccionar otras formas de producción y distribución de las películas, a través de Netflix, los directores evaden la barrera de los monopolios impuestos por los medios nacionales en cada país, para alcanzar un público no sólo local

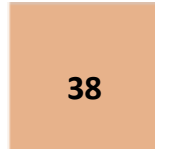

Cuadernos del CILHA n $34-2021$

ISSN 1515-6125 | EISSN 1852-9615

CC BY-NC 2.5 AR

http://revistas.uncu.edu.ar/ojs/index.php/cilha/ 
sino también internacional. Esto a su vez les facilita la posibilidad de crear historias que no pasen por los filtros de censura nacional. Los objetivos tanto pedagógicos en Crímenes de familia, y de denuncia en Las tres muertes de Marisela Escobedo, se potencializan al llegar a un público más extenso y con esto concientizar al espectador de la gravedad de la violencia de género. Estas películas sensibilizan a los diferentes públicos por medio de la construcción de la perspectiva de la madre para combatir la normalización de la violencia de género. En ese sentido, explicamos que Segato propone como estrategia para combatir la violencia, una contra-pedagogía de la crueldad con el objetivo de crear y nutrir relaciones que enseñen a valorar a las personas como personas. A lo largo de nuestro análisis, argumentamos que Crímenes de familia y Las tres muertes de Marisela Escobedo ofrecen una lectura en el sentido mencionado por Segato. Ambas funcionan como estrategias de contra-pedagogía de la crueldad, por el tratamiento que hacen de la violencia de género al humanizar a sus protagonistas, contextualizando la razón de la fuente que genera la violencia. Además, con las acciones de los personajes se exhorta a formar lazos comunitarios por medio de la sororidad para combatir la violencia.

\section{Referencias}

Amado, A. M., \& Domínguez, N. (2004). Lazos de familia: herencias, cuerpos, ficciones (vol. 13). Ediciones Paidos Iberica.

Arredondo, I. (2014). Motherhood in Mexican Cinema, 1941-1991. The Transformation of Femininity on Screen. McFarland \& Company.

Arteaga, N., \& Váldes, J. (2010). Contextos socioculturales de los feminicidios en el Estado de México: Nuevas subjetividades femeninas. Revista Mexicana de Sociología, 72(1), 5-35. http://www.jstor.org/stable/25677030

Aviña, R. (2014). Una mirada insólita. Temas y géneros del cine mexicano. Cineteca Nacional/ Oceano. 
De crímenes de familia a crímenes de Estado. La figura de la madre en la lucha contra la violencia de género en Crímenes de familia (2020) y Las tres muertes de Marisela Escobedo (2020)

Baladrón, M., \& Rivero, E. (2019). Video-on-demand services in Latin America: Trends and challenges towards access, concentration and regulation. Journal of Digital Media \& Policy, 10 (1), 109-126.

https://doi-org.proxy-sm.researchport.umd.edu/10.1386/jdmp.10.1.109_1

Bordwell, D., Thompson, Kristin. (2008). Film art: An introduction (Eight ed.). University of Wisconsin.

Burton J. (1990). The Social Documentary in Latin America. University of Pittsburgh Press.

Fregoso, R. L. (2009). “iLas queremos vivas!": la política y cultura de los derechos humanos. Debate Feminista, 39 (20), 209-243.

Convención Interamericana para prevenir, sancionar y erradicar la violencia contra la Mujer (6/9/1994). Convención De Belem Do Para.

https://www.oas.org/juridico/spanish/firmas/a-61.html

Cornelio-Marí, E. M. (2020). Melodrama mexicano en la era de Netflix: algoritmos para la proximidad cultural. Comunicación y Sociedad, 17, 1-27. https://doi.org/10.32870/cys.v2020.7481

Incháustegui Romero, T. (2014). Sociología y política del feminicidio; algunas claves interpretativas a partir del caso mexicano. Sociedade e Estado, 29 (2), 373-400.

La casa del encuentro (2021). Feminismo popular entre todas las mujeres y con la sociedad. http://www.lacasadelencuentro.org/

La equipa editorial. (8 marzo 2020). \#8M: Como nunca antes, una potente marcha de mujeres lanza grito contra el machismo y violencia feminicida. Animal politico. https://www.animalpolitico.com/2020/03/mujeres-marcha-8m-cdmx-protestamachistmo/

Laudano, C. N. (2010). Visibilidad mediática de la violencia hacia las mujeres: continuidades y cambios en Argentina (1983-2009). Derecho y ciencias sociales, 88-110.

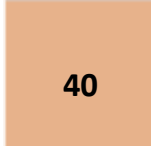

Cuadernos del CILHA n $34-2021$

ISSN 1515-6125 | EISSN 1852-9615

CC BY-NC 2.5 AR

http://revistas.uncu.edu.ar/ojs/index.php/cilha/ 
Ludmer, J. (2002). Temporalidades del presente. Margens/Márgenes: Revista de Cultura, 2, 14-27.

Lugones, M. (2007). Heterosexualism and the colonial/modern gender system. Hypatia, 22 (1), 186-219.

Lugones, M. (2008). Colonialidad y género. Tabula rasa, 9, 73-101.

Maradei, G. (2016). Cuerpos que inciden: Familia, matrimonio y maternidad en la literatura argentina de la última década. Chasqui, 45 (1), 246-263.

Mármol, H. (19 de febrero de 2020). 4.5 millones de usuarios Argentina está entre los 10 países con más suscriptores de Netflix. Clarín Tecnología.

https://www.clarin.com/tecnologia/argentina-10-paises-suscriptores-netflixmundo_0_gqaLXSjU.html

Ministerio de Cultura Argentina. (22 de agosto de 2020). Crímenes de familia, la última película de Sebastian Schindel, disponible en Cine.AR. https://www.cultura.gob.ar/entrevista-sebastian-schindel-9398/

Monárrez, J. (1993). Las diversas representaciones del feminicidio y los asesinatos de mujeres en Ciudad Juárez. En M. Fragoso, C. Gómez, F. Flores, M. César y R. Salar (eds), Violencia contra las mujeres e inseguridad ciudadana en Ciudad Juárez, 353-398. El Colef, Miguel Ángel Porrúa.

ONU Mujeres. (25 de noviembre de 2018). La violencia contra las mujeres no es normal ni tolerable. Garantizar los derechos humanos de las mujeres y las niñas es trabajo de todas $y$ de todos. https://mexico.unwomen.org/es/noticias-yeventos/articulos/2018/11/violencia-contra-las-mujeres

OM. Oficina de la Mujer (29 de mayo de 2021) Registro Nacional de Femicidios: "Se cometió un femicidio directo cada 35 horas". https://www.csjn.gov.ar/om/verNoticia.do?idNoticia=4943 
De crímenes de familia a crímenes de Estado. La figura de la madre en la lucha contra la violencia de género en Crímenes de familia (2020) y Las tres muertes de Marisela Escobedo (2020)

Orozco Mendoza, E. F. (2019). Las Madres De Chihuahua: Maternal Activism, Public Disclosure, and the Politics of Visibility. New Political Science, 41 (2), 211-233.

Pagnoni Berns, F. G. (2016). Motherhood and Identity in Contemporary Argentine Cinema. In A. Sayed (ed.), Screening motherhood in contemporary world cinema (pp. 365-389). Demeter Press.

Palmeiro, C. (2019). Ni Una Menos: las lenguas locas del grito colectivo a la marea global. Cuadernos de Literatura, 23 (46), 177-195.

Pereda Martínez, A. (29 de mayo 2019). Asesinatos de mujeres, un delito que va al alza. El Universal. https://www.eluniversal.com.mx/estados/cada-dos-horas-y-mediamatan-una-mujer-en-mexico

Pérez Osorio, C. (Director) (2020). Las tres muertes de Marisela Escobedo. Netflix Studios.

Santos, C. (2016). Maligned Mothers: From Coatlicue to La Malinche and back. In A. Sayed (ed.), Screening motherhood in contemporary world cinema. Demeter Press.

Sayed, A. (2016). Intersectional Interventions in Global Cinema. Introducing the maternal. In A. Sayed (ed.), Screening motherhood in contemporary world cinema (pp. 34-37). Demeter Press.

Segato, R. (2003). Las estructuras elementales de la violencia: contrato y status en la etiología de la violencia. Série Antropologia, 334, 1-19.

Segato, R. (2008). La escritura en el cuerpo de las mujeres asesinadas en Ciudad Juárez: territorio, soberanía y crímenes de segundo estado. Debate Feminista, 37 (19), 78-102.

Segato, R. (2018). A Manifesto in Four Themes. Critical Times, 1 (1), 198-211.

Segato, R. (4 de enero de 2021). Crueldad: Pedagogías y Contra-Pedagogías. Lobo Suelto Anarquia Coronada http://lobosuelto.com/crueldad-pedagogias-y-contra-pedagogiasrita-segato/ 
Schindel, S. (dir.). (2020). Crímenes de familia [Film]. Buffalo Films, Magoya Films, Tieless Media.

Tiscareño García, E., \& Miranda Villanueva, O. M. (2020). Víctimas y victimarios de feminicidio en el lenguaje de la prensa escrita mexicana. Comunicar, Revista Científica iberoamericana de comunicación y educación, 63, 51-60. https://doi-org.proxysm.researchport.umd.edu/10.3916/C63-2020-05

Tuñón J. (1998). Mujeres de luz y sombra en el cine mexicano: La construcción de una imagen (1939-1952). El Colegio de México/Instituto Mexicano de Cinematografía.

Yanal, Robert J. (1996). The Paradox of Suspense. The British Journal of Aesthetics, 36 (2), 146-158.

Wilson, T. (2014). Introduction: Violence against Women in Latin America. Latin American Perspectives, 41 (1), 3-18. http://www.jstor.org/stable/24573973 